\title{
Continuously Stirred Tank Reactor Parameters That Affect Sludge Batch 6 Simulant Properties
}

\author{
J.D. Newell \\ D.P. Lambert \\ M.E. Stone \\ A.I. Fernandez
}

May 2010

Savannah River National Laboratory Savannah River Nuclear Solutions Aiken, SC 29808

Prepared for the U.S. Department of Energy under contract number DE-AC09-08SR22470.

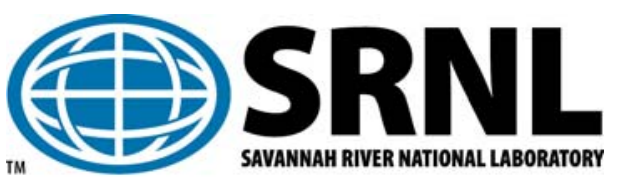


SRNL-STI-2009-00603

Revision 0

\section{DISCLAIMER}

This work was prepared under an agreement with and funded by the U.S. Government. Neither the U.S. Government or its employees, nor any of its contractors, subcontractors or their employees, makes any express or implied:

1. warranty or assumes any legal liability for the accuracy, completeness, or for the use or results of such use of any information, product, or process disclosed; or

2. representation that such use or results of such use would not infringe privately owned rights; or

3. endorsement or recommendation of any specifically identified commercial product, process, or service.

Any views and opinions of authors expressed in this work do not necessarily state or reflect those of the United States Government, or its contractors, or subcontractors.

\section{Printed in the United States of America \\ Prepared for \\ U.S. Department of Energy}




\section{REVIEWS AND APPROVALS}

AUTHORS:

J.D. Newell, Process Engineering Technology

D.P. Lambert, Process Engineering Technology

M.E. Stone, Process Engineering Technology

A.I. Fernandez, Process Engineering Technology

TECHNICAL REVIEW:

B.R. Pickenheim, Process Engineering Technology

Date

APPROVAL:

C.C. Herman, Manager

Process Engineering Technology

S.L. Marra, Manager

Date

Environmental \& Chemical Process Technology Research Programs

J. E. Occhipinti, Manager

Process Cognizant Engineering, Waste Solidification Engineering
Date

Date

Date

Date
Date

Date 


\section{ACKNOWLEDGEMENTS}

A portion of this work was accomplished by Eddie Newman during the 2009 summer internship program. Statistical analysis was performed by Dr. Tommy Edwards. Particle size analyses were performed by Analytical Development. The authors would like to acknowledge the technical support from David Healy, Jon DuVall, and Debbie Marsh. 


\section{EXECUTIVE SUMMARY}

Significant differences in the physical properties of simulated wastes are observed depending on the preparation route selected. The preferred method for making simulant is by using a continuously stirred tank reactor (CSTR). There are several parameters that control the physical properties of the simulant. This work focuses on determining the effect of varying the parameters of $\mathrm{pH}$, temperature, flow rate, and mixing speed during the simulant preparation for the purpose of making a simulant that is more prototypical of Savannah River Site sludge that is transferred to the Defense Waste Processing Facility (DWPF) for processing.

A matrix was developed to establish the ranges of the parameters being investigated. Temperature was varied from $22-70{ }^{\circ} \mathrm{C}, \mathrm{pH}$ from $9-14$, flow rate $30-250 \mathrm{ml} / \mathrm{min}$, and mixing speed 350-1000 rpm. A series of 10 batches was made in the continuous stirred tank reactor (CSTR) using a sludge batch 6 composition. These batches were analyzed to determine the changes in particle size, rheology, and foaming. Data was analyzed using JMP statistical software to determine the aggregate effect of varying the parameters.

By varying the parameters stated above for the precipitation process, the following effects and correlations were observed for the ten batches prepared:

\section{Particle Size}

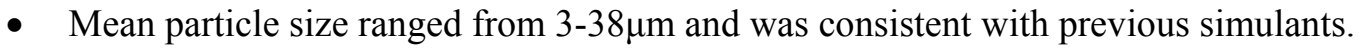

- Changes in $\mathrm{pH}$, flow rate, and mixing speed are statistically significant with respect to particle size.

- The effect of flow rate and mixing speed are linear while that of $\mathrm{pH}$ is quadratic. Results indicated that a lower $\mathrm{pH}$ produces smaller particles.

\section{$\underline{\text { Rheology }}$}

- Increasing wt.\% insoluble solids increases yield stress, as expected.

- Changes in $\mathrm{pH}$, flow rate, temperature, and mixing speed are statistically significant with respect to yield stress.

- The effect of the tested parameters is linear.

- By varying the parameters tested, it appears that simulant yield stress could be adjusted to targeted value.

\section{Foaming}

- Increasing mixing speed had a slight effect on increasing simulant foaming.

- Changes in $\mathrm{pH}$, flow rate, and temperature had no effect on foaming.

Recommendations

The work performed for this study looked at four parametric effects for simulant SB6A. This resulted in 10 distinct batches for analysis. This was the least number of batches that could be prepared and still have the statistical ability to determine the individual effects of these parameters on the physical properties of simulant particle size, rheology, and foaming. For a more accurate correlation of the influence of these parameters, an additional 10 batches would need to be prepared and tested. SRNL is currently partnering with foam experts at the Illinois Institute of Technology (IIT). IIT will perform a study on simulants provided to them by SRNL. Their recommendations will be incorporated into a future test program. 


\section{TABLE OF CONTENTS}

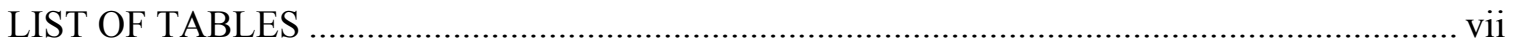

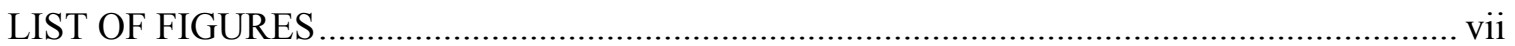

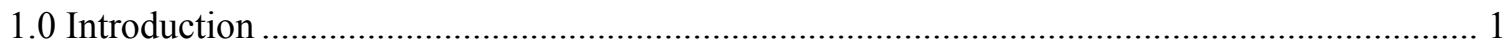

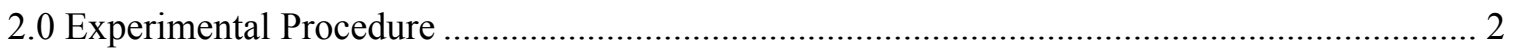

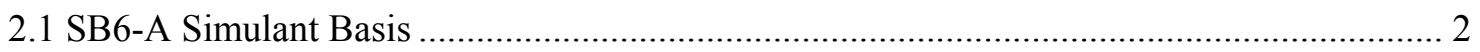

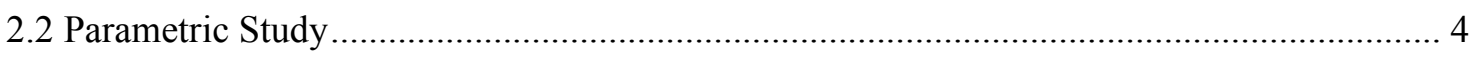

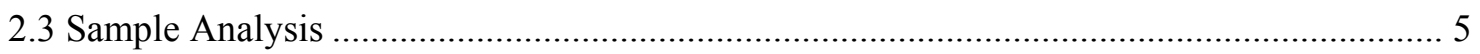

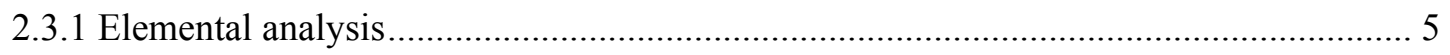

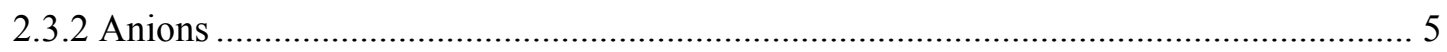

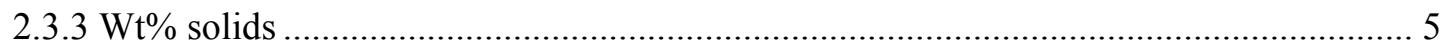

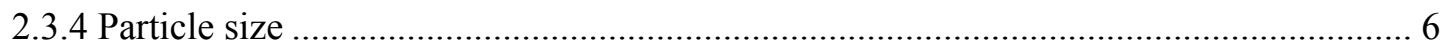

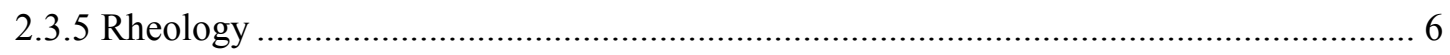

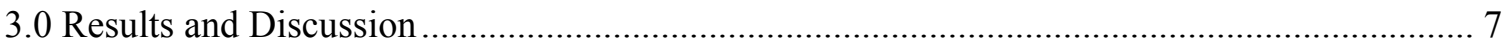

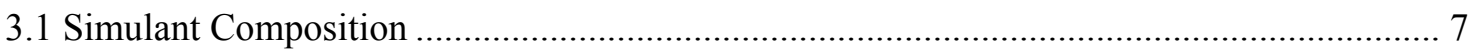

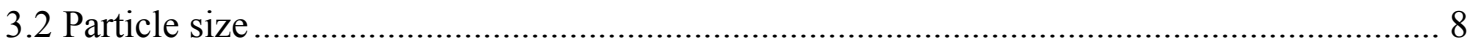

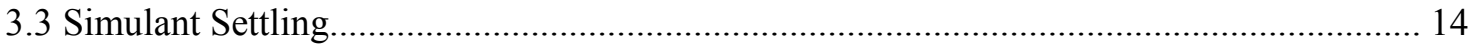

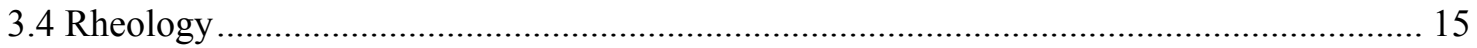

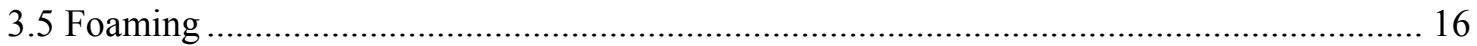

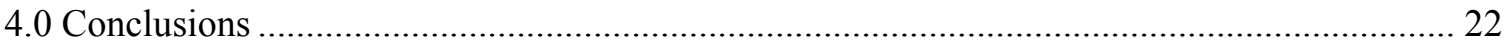

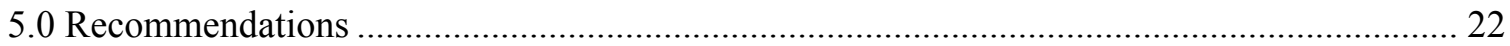

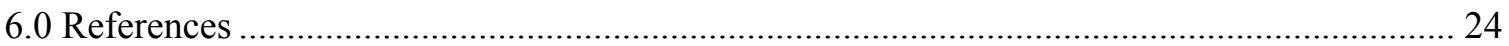

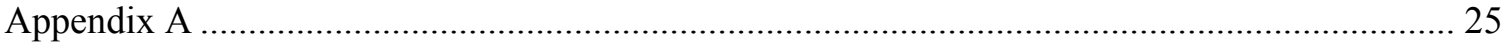




\section{LIST OF TABLES}

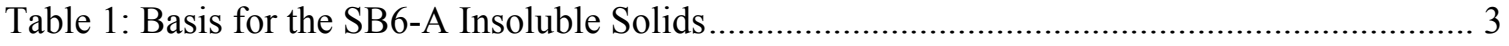

Table 2: Basis for the SB6-A Supernate

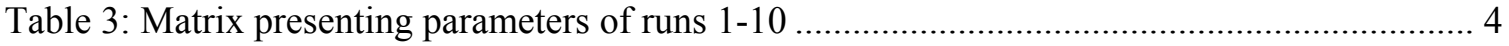

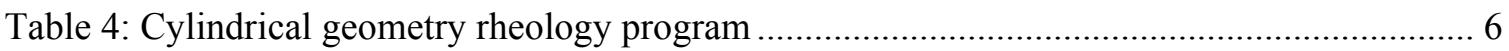

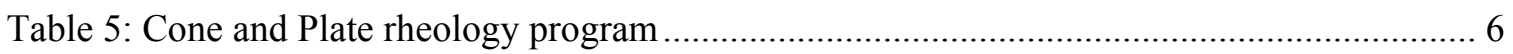

Table 6: Elemental wt.\% composition of runs 1A-10 ............................................................... 7

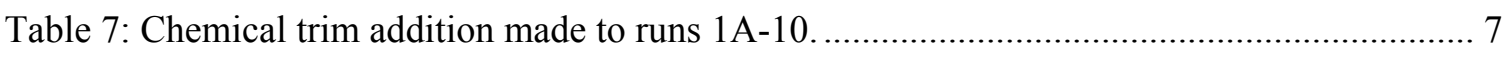

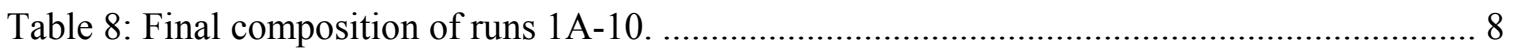

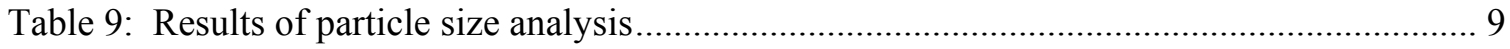

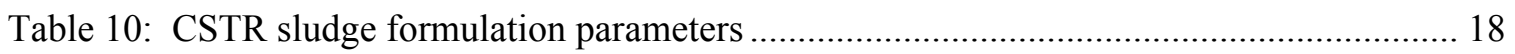

\section{LIST OF FIGURES}

Figure 1: Graphical representation of simulant development process using CSTR ..................... 2

Figure 2: Mean volume distribution for SB6A batch 1A........................................................ 9

Figure 3: Mean particle size for SB6A simulant batches. ....................................................... 10

Figure 4: JMP software analysis of parametric effect on particle size...................................... 11

Figure 5: JMP software analysis of the effect of $\mathrm{pH}$ on simulant particle size. …...................... 12

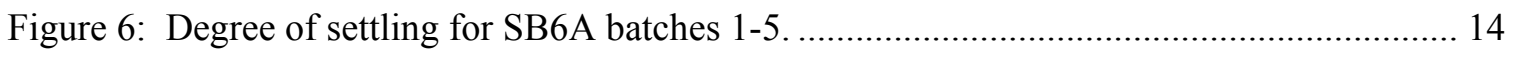

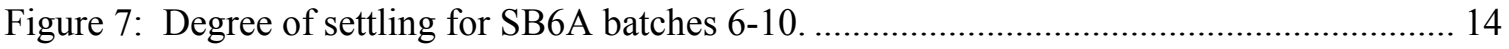

Figure 8: Yield stress summary of SB6A simulant batches 1-10, relative to wt.\% insoluble solids

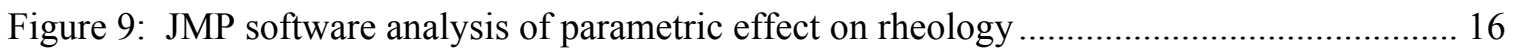

Figure 10: Foaming height versus particle size distribution.................................................... 17

Figure 11: Foaming height (average and maximum) vs. mixing speed .................................... 19

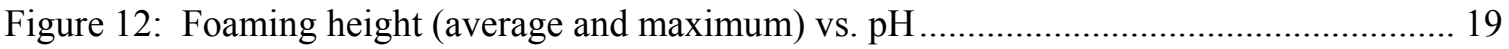

Figure 13: Foaming height (average and maximum) vs. flow rate ........................................... 20

Figure 14: Foaming height (average and maximum) vs. temperature ....................................... 21 


\section{LIST OF ABBREVIATIONS}

ACTL

$\mathrm{AD}$

CSTR

DWPF

HLW

PSAL

SB

SRNL

SRS
Aiken County Technology Laboratory

Analytical Development

Continuous Stirred Tank Reactor

Defense Waste Processing Facility

High Level Waste

Process Science Analytical Laboratory

Sludge Batch

Savannah River National Laboratory

Savannah River Site 


\subsection{Introduction}

The High Level Radioactive Waste (HLW) Sludge in Savannah River Site (SRS) waste tanks was produced over a period of over 60 years by neutralizing the acidic waste produced in the $\mathrm{F}$ and $\mathrm{H}$ Separations Canyons with sodium hydroxide. The HLW slurries have been stored at free hydroxide concentrations above $1 \mathrm{M}$ to minimize the corrosion of the carbon steel waste tanks. Sodium nitrite is periodically added as a corrosion inhibitor. The resulting waste has been subjected to supernate evaporation to minimize the volume of the stored waste. In addition, some of the waste tanks experienced high temperatures so some of the waste has been at elevated temperatures. Because the waste is radioactive, the waste is transforming through the decay of shorter lived radioactive species and the radiation damage that the decay releases. The goal of the Savannah River National Laboratory (SRNL) simulant development program is to develop a method to produce a sludge simulant that matches both the chemical and physical characteristics of the HLW without the time, temperature profile, chemical or radiation exposure of that of the real waste.

Several different approaches have been taken historically toward preparing simulated waste slurries [1-2]. All of the approaches used in the past dozen years involve some precipitation of the species using similar chemistry to that which formed the radioactive waste solids in the tank farm. All of the approaches add certain chemical species as commercially available insoluble solid compounds. The number of species introduced in this manner, however, has varied widely. All of the simulant preparation approaches make the simulated aqueous phase by adding the appropriate ratios of various sodium salts. The simulant preparation sequence generally starts with an acidic $\mathrm{pH}$ and ends up with a caustic $\mathrm{pH}$ (typically in the 10-12 range).

The current method for making sludge simulant involves the use of a temperature controlled continuously stirred tank reactor (CSTR). Precipitated $\mathrm{MnO}_{2}$ is combined with metal nitrates and fed into the CSTR. The metals are precipitated by a caustic $\mathrm{NaOH}$ stream. The rates at which these streams are added allows for $\mathrm{pH}$ adjustment of the mixture. A graphical representation of this process is given in Figure 1. In using the CSTR method for developing simulant, there are various parameters that can be adjusted in order to effectuate a physical change in the resulting simulant: $\mathrm{pH}$, temperature, mixing speed, and flow rate. How will changing these parameters affect the physical properties of the sludge simulant? The ability to determine which parameter affects a particular property could allow one to develop a simulant that would better match the physical characteristics of HLW sludge. 
Figure 1: Graphical representation of simulant development process using CSTR.

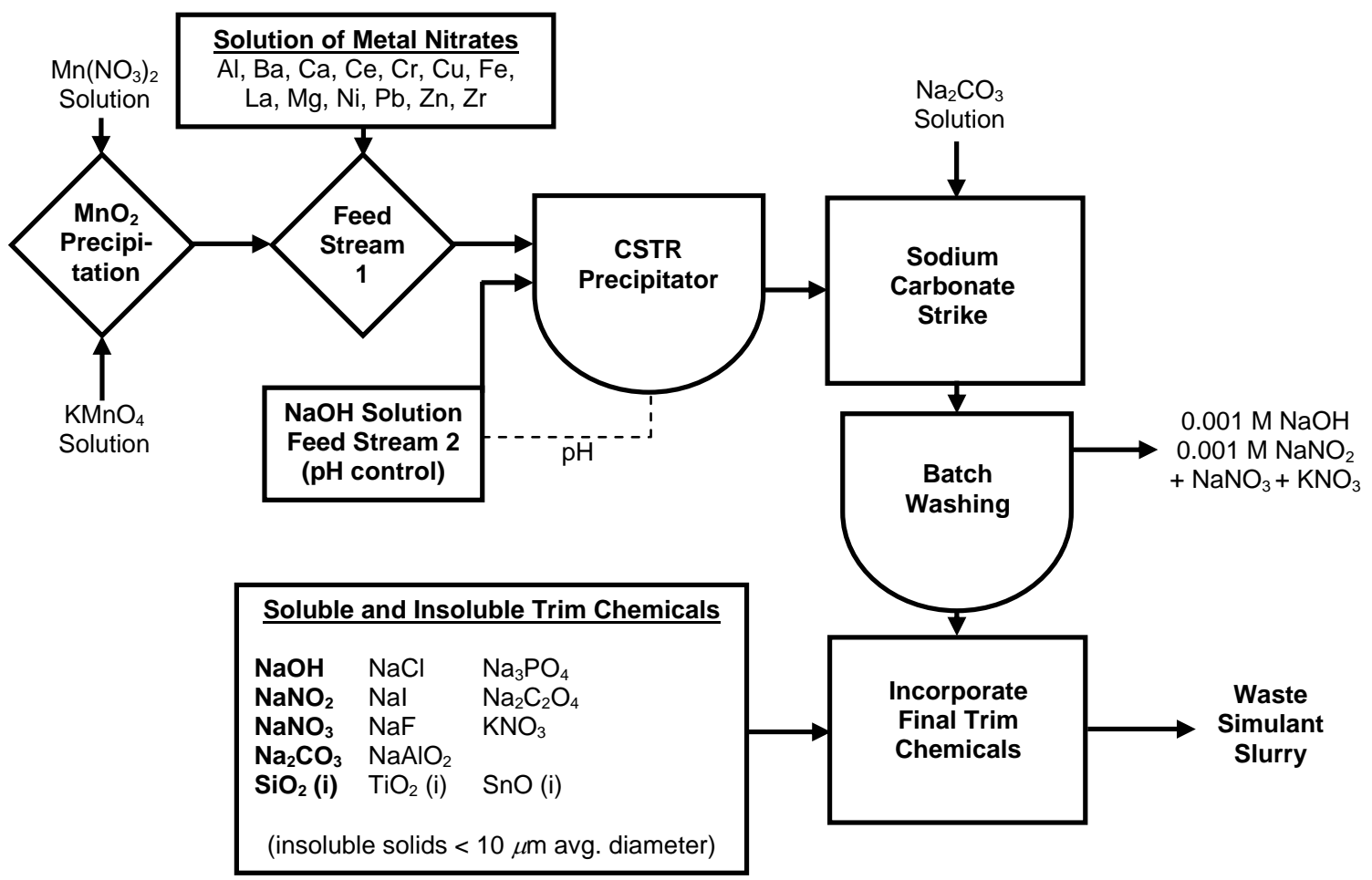

\subsection{Experimental Procedure}

\subsection{SB6-A Simulant Basis}

The simulant used in these experiments was Sludge Batch 6-A (SB6-A). The characterization and methods with which this sludge simulant was precipitated, washed and trimmed has been previously reported[3].

The simulant basis for insoluble solids was taken from "Sludge Batch 6 Projected Batch and Blend Compositions", LWO-LWP-2009-00001 (Table 1). The simulant basis for the supernate was "Flowsheet for Aluminum Removal from Sludge Batch 6", SRNL-STI-2008-00389 (Table 2). Note that no surrogate was used for uranium. All other elements, with the exception of sodium, were re-normalized. 
Table 1: Basis for the SB6-A Insoluble Solids

\begin{tabular}{|c|c|c|c|}
\hline \multicolumn{2}{|c|}{ FEED DENSITY (INPUT) } & 1.12 & $\overline{\mathrm{G} / \mathrm{ML}}$ \\
\hline \multicolumn{2}{|c|}{ Insoluble Solids wt \% } & 11.96 & \\
\hline \multicolumn{2}{|c|}{ Insoluble Solids, mass/Liter } & 133.95 & $\mathrm{~g} / \mathrm{L}$ \\
\hline \multicolumn{2}{|c|}{ Total Solids wt $\%$} & 17.31 & \\
\hline \multicolumn{2}{|c|}{ Total Solids, mass/Liter } & 193.87 & $\mathrm{~g} / \mathrm{L}$ \\
\hline Element & Total Solids Wt \% & Oxides & Wt \% Oxides \\
\hline $\mathrm{Al}$ & 12.92 & $\mathrm{Al}_{2} \mathrm{O}_{3}$ & 24.41 \\
\hline $\mathrm{Ba}$ & 0.21 & $\mathrm{BaO}$ & 0.23 \\
\hline $\mathrm{Ca}$ & 1.88 & $\mathrm{CaO}$ & 2.63 \\
\hline $\mathrm{Ce}$ & 0.18 & $\mathrm{Ce}_{2} \mathrm{O}_{3}$ & 0.21 \\
\hline $\mathrm{Cr}$ & 0.30 & $\mathrm{Cr}_{2} \mathrm{O}_{3}$ & 0.44 \\
\hline $\mathrm{Cu}$ & 0.09 & $\mathrm{CuO}$ & 0.11 \\
\hline $\mathrm{Fe}$ & 16.21 & $\mathrm{Fe}_{2} \mathrm{O}_{3}$ & 23.18 \\
\hline $\mathrm{K}$ & 0.04 & $\mathrm{~K}_{2} \mathrm{O}$ & 0.05 \\
\hline $\mathrm{La}$ & 0.09 & $\mathrm{La}_{2} \mathrm{O}_{3}$ & 0.11 \\
\hline $\mathrm{Mg}$ & 1.33 & $\mathrm{MgO}$ & 2.21 \\
\hline $\mathrm{Mn}$ & 6.16 & $\mathrm{MnO}_{2}$ & 9.75 \\
\hline $\mathrm{Na}$ & 18.61 & $\mathrm{Na}_{2} \mathrm{O}$ & 25.09 \\
\hline $\mathrm{Ni}$ & 3.52 & $\mathrm{NiO}$ & 4.48 \\
\hline $\mathrm{Pb}$ & 0.14 & $\mathrm{PbO}$ & 0.15 \\
\hline $\mathrm{Si}$ & 0.52 & $\mathrm{SiO}_{2}$ & 1.11 \\
\hline $\mathrm{Th}$ & 1.26 & $\mathrm{ThO}_{2}$ & 1.43 \\
\hline $\mathrm{Ti}$ & 0.02 & $\mathrm{TiO}_{2}$ & 0.03 \\
\hline $\mathrm{U}$ & 4.67 & $\mathrm{U}_{2} \mathrm{O}_{3}$ & 5.14 \\
\hline $\mathrm{Zn}$ & 0.13 & $\mathrm{ZnO}$ & 0.16 \\
\hline $\mathrm{Zr}$ & 0.37 & $\mathrm{ZrO}_{2}$ & 0.50 \\
\hline
\end{tabular}


SRNL-STI-2009-00603

Revision 0

Table 2: Basis for the SB6-A Supernate

\begin{tabular}{||l|l||}
\hline SUPERNATE TARGET INPUTS & \\
\hline Liquid Volume (gal) & 281,000 \\
\hline $\mathrm{SpG}, \mathrm{kg} / \mathrm{L}$ & 1.035 \\
\hline $\mathrm{Na}^{+}, \mathrm{M}$ & 1.01 \\
\hline $\mathrm{NO}_{2}{ }^{-}, \mathrm{M}$ & 0.34 \\
\hline $\mathrm{NO}_{3}{ }^{-}, \mathrm{M}$ & 0.18 \\
\hline $\mathrm{OH}^{-}, \mathrm{M}$ & 0.29 \\
\hline $\mathrm{Cl}^{-}, \mathrm{M}$ & 0.00409 \\
\hline $\mathrm{SO}_{4}{ }^{-2}, \mathrm{M}$ & 0.019 \\
\hline $\mathrm{F}^{-}, \mathrm{M}$ & 0.00069 \\
\hline $\mathrm{CO}_{3}{ }^{-2}, \mathrm{M}$ & 0.05 \\
\hline $\mathrm{AlO}^{2-}, \mathrm{M}$ & 0.05 \\
\hline $\mathrm{C}_{2} \mathrm{O}_{4}^{-}{ }^{2} \mathrm{M}$ & 0.0041 \\
\hline $\mathrm{PO}_{4}{ }^{-3}, \mathrm{M}$ & 0.00046 \\
\hline $\mathrm{K}^{+}, \mathrm{M}$ & 0.0032 \\
\hline \hline
\end{tabular}

\subsection{Parametric Study}

A matrix detailing the parameter values was created and is represented in Table 3 . The matrix was initially set up into two blocks. Completion of block 1 will provide the data needed to determine if continuation with Block 2 is justified. This study focuses solely on block $1 . \mathrm{pH}$ will be examined over the range of $9-14$, flow rate from $20-360 \mathrm{~mL} / \mathrm{min}$, temperature $22-85 \mathrm{C}$, and mixing 100-1000 $\mathrm{rpm}^{\mathrm{i}}$.

Table 3: Matrix presenting parameters of runs 1-10

\begin{tabular}{||c|c|c|cc|c|c||}
\hline run & block & $\begin{array}{c}\text { targeted } \\
\mathbf{p H}\end{array}$ & $\begin{array}{c}\text { measured } \\
\mathbf{p H}\end{array}$ & $\begin{array}{c}\text { flow } \\
\text { rate } \\
(\mathbf{m l / m i n})\end{array}$ & $\begin{array}{c}\text { temperature } \\
\left({ }^{\circ} \mathbf{C}\right)\end{array}$ & $\begin{array}{c}\text { mixing } \\
\text { speed } \\
(\mathbf{r p m})\end{array}$ \\
\hline 1 & 1 & 11.5 & 13.2 & 140 & 46 & 550 \\
\hline 2 & 1 & 14 & 14.2 & 250 & 22 & 1000 \\
\hline 3 & 1 & 14 & 14.0 & 30 & 22 & 350 \\
\hline 4 & 1 & 9 & 9.0 & 250 & 22 & 350 \\
\hline 5 & 1 & 9 & 9.4 & 30 & 22 & 1000 \\
\hline 6 & 1 & 14 & 14.0 & 250 & 70 & 350 \\
\hline 7 & 1 & 9 & 11.5 & 250 & 70 & 1000 \\
\hline 8 & 1 & 14 & 14.3 & 30 & 70 & 1000 \\
\hline 9 & 1 & 9 & 11.2 & 30 & 70 & 350 \\
\hline 10 & 1 & 11.5 & 13.8 & 140 & 46 & 550 \\
\hline
\end{tabular}

${ }^{\mathrm{i}}$ It was determined after the first run that a mixing speed of $100 \mathrm{rpm}$ was insufficient to produce a well-mixed simulant within the CSTR, therefore, the lower mixing limit was increased to $350 \mathrm{rpm}$. 
The matrix was set up with the assumption that changes in particle size would be linear with respect to the parameters being changed. Upon completion of Block 1, the data was to be evaluated to determine if linearity exits. If not, additional runs would be included to determine the mathematical relationship (i.e. linear, logarithmic, quadratic, etc.).

Each run had a different set of parameters, except for the first and last runs of the block which were identical for both blocks. For changes to temperature, the feed pumps were stopped until the new temperature was reached. For all parametric changes, in order to ensure that the system had time to equilibrate to the new changes, each run discarded seven volume turnovers of the CSTR. This is similar to exponential decay. Each volume turnover represents a half-life. After the seventh turnover, it is estimated that only 0.781 percentage remains of the simulant based on the previous parameters. The eighth volume was collected for analysis. The "discarded" seven volume turnovers from all ten runs were collected into one drum for use in other programs.

A run plan was drafted that provided details on the chemical composition of the simulant. Ten separate batches were made at a volume of ten liters. It was determined that having separate batches would help ensure good mixing and homogeneity of the feed. Details of the CSTR run plan have been previously published [5].

\subsection{Sample Analysis}

\subsubsection{Elemental analysis}

Samples of each finished simulant were analyzed at the Process Science Analytical Laboratory (PSAL) to determine the elemental chemical composition. The slurry composition was determined as follows. Duplicate samples were calcined at $1100{ }^{\circ} \mathrm{C}$, and then the solids were dissolved using either a $\mathrm{Na}_{2} \mathrm{O}_{2} / \mathrm{NaOH}$ fusion or a lithium tetraborate/lithium nitrate fusion. The preparations were then analyzed using a Varian Vista Axial Inductively Coupled Plasma Atomic Emission Spectrometer (AXICP-AES) to measure the cations present.

\subsubsection{Anions}

Slurry samples for anion analyses were prepared by PSAL using weighted dilutions and were analyzed using a Dionics DX500 Ion Chromatograph (IC). Weighted dilutions involved diluting a known mass of slurry with a known mass of de-ionized water. The resulting slurry was filtered. The solid free liquid was further diluted as necessary with de-ionized water to obtain IC readings within the calibration range of the instrument.

\subsubsection{Wt\% solids}

A slurry sample of known mass was introduced and dried at about $110{ }^{\circ} \mathrm{C}$. The mass loss was used to determine the $\mathrm{wt} \%$ total solids of the slurry. A slurry sample was also filtered or centrifuged to remove $99.9 \%$ of the insoluble solids. A known mass of filtrate was introduced and dried at about $110^{\circ} \mathrm{C}$. The mass loss was used to determine the $\mathrm{wt} \%$ total solids of the supernate, or the "wt\% dissolved solids". The two values were combined algebraically to calculate the wt $\%$ insoluble solids of the slurry and the wt $\%$ soluble solids of the slurry. Solids analyses were performed in duplicate using two separate aliquots of sample for each measurement. 


\subsubsection{Particle size}

Particle size analysis was obtained by submitting samples to Analytical Development for analysis. Samples were analyzed with a Microtrac S3500 Tri-laser Particle Size Analyzer. This instrument uses angular light scattering techniques to measure the particle size distribution. Preparation of the samples for analysis by the Microtrac consists of dilution of the slurry with water. The particle size distribution can be expressed in terms of a volume distribution, number distribution or area distribution. In this report, the graphical display of particle size data will use the particle diameter and number distributions. The calculated mean of the volume, number and area distributions will also be reported. It should be noted that the mean for a volume distribution is weighted toward the larger particles while the mean for the number distribution is weighted toward the smallest particles. The calculated specific surface area in meters $/ \mathrm{cm}^{3}$ is based on an assumption of smooth, solid spherical particles and does not reflect porosity or topology of the particles.

\subsubsection{Rheology}

Slurry rheology measurements were performed using a Haake RS600 rheometer at $25{ }^{\circ} \mathrm{C}$. The rheometer uses a Searle type measuring system, where both speed and torque are measured at the rotating shaft. The rheometer was operated in the controlled rate mode for all of the data reported in this report. A few measurements were also made in the controlled stress mode when additional clarification of a rheology result was needed. The measuring geometries used were the cylindrical sensor and cup (Z41 Ti) for the less viscous slurries and the cone and plate (35 $\mathrm{mm} \mathrm{Ti} / 4$ degree) for the slurries that were too thick for loading into the cylindrical geometry.

Flow curves were obtained by linearly varying the shear rate from 0 to 500 seconds $^{-1}$ over a given time period. The program details for the flow curves are listed in Table 4 and Table 5 for the cylindrical and cone geometries respectively. The measured shear stresses for the down flow curves were fitted to the Bingham Plastic rheology model over the shear rate range of 50 to 500 seconds ${ }^{-1}$. Within this report, up curves are reported.

Table 4: Cylindrical geometry rheology program

\begin{tabular}{|c|c|c||}
\hline $\begin{array}{c}\text { PROGRAM } \\
\text { SECTION }\end{array}$ & $\begin{array}{c}\text { SHEAR RATE } \\
\text { (SEC }^{-1} \text { ) }\end{array}$ & $\begin{array}{c}\text { TIME } \\
\text { (MIN) }\end{array}$ \\
\hline Up Curve & 0 to 500 & 5 \\
\hline Hold Period & 500 & 2 \\
\hline Down Curve & 500 to 0 & 5 \\
\hline
\end{tabular}

Table 5: Cone and Plate rheology program

\begin{tabular}{||c|c|c||}
\hline $\begin{array}{c}\text { PROGRAM } \\
\text { SECTION }\end{array}$ & $\begin{array}{c}\text { SHEAR RATE } \\
\text { (SEC }\end{array}$ & $\begin{array}{c}\text { - } \\
\text { TIME } \\
\text { (MIN) }\end{array}$ \\
\hline Initial Hold & 0 & 2 \\
\hline $1^{\text {st }}$ Up Curve & 0 to 500 & 5 \\
\hline $1^{\text {st }}$ Hold & 500 & 2 \\
\hline $1^{\text {st }}$ Down Curve & 500 to 0 & 5 \\
\hline Hold & 0 & 2 \\
\hline $2^{\text {nd }}$ Up Curve & 0 to 500 & 5 \\
\hline $2^{\text {nd }}$ Hold & 500 & 2 \\
\hline $2^{\text {nd }}$ Down Curve & 500 to 0 & 5 \\
\hline
\end{tabular}




\subsection{Results and Discussion}

\subsection{Simulant Composition}

Samples from runs $1 \mathrm{~A}^{\mathrm{i}}-10$ were analyzed for chemical composition. As can be seen in Table 6 , compositional variation appears to be greatest for aluminum and sodium for runs 2, 3, 6, 8, and 10. These runs correspond to ones that tested the effect of higher $\mathrm{pH}$. One of the known effects of higher $\mathrm{pH}$ is metal dissolution. Run 5 was used as a final target, as all other runs could be normalized relative to it. Aluminum to iron ratios were kept constant for all runs. In order to normalize the compositions, chemical trim additions were made (Table 7) in order to achieve the final composition reported in Table 8 .

Table 6: Elemental wt.\% composition of runs 1A-10.

\begin{tabular}{|c|c|c|c|c|c|c|c|c|c|c|c|c|c|c|c|c|c|}
\hline Run & Al & Ba & Ca & Ce & $\mathrm{Cr}$ & $\mathbf{C u}$ & $\mathbf{F e}$ & K & Mg & Mn & Na & $\mathbf{N i}$ & $\mathbf{P b}$ & S & Si & Zn & $\mathrm{Zr}$ \\
\hline 1A & 14.41 & 0.32 & 2.77 & 0.24 & 0.35 & 0.14 & 22.55 & 0.08 & 1.94 & 12.21 & 1.32 & 4.96 & 0.16 & 0.04 & 0.03 & 0.20 & 0.71 \\
\hline 2 & 4.33 & 0.16 & 4.01 & 0.35 & 0.35 & 0.19 & 31.70 & 0.01 & 2.83 & 12.47 & 0.56 & 7.16 & 0.05 & 0.04 & 0.04 & 0.28 & 0.32 \\
\hline 3 & 4.54 & 0.21 & 3.80 & 0.33 & 0.32 & 0.18 & 30.10 & 0.06 & 3.51 & 13.19 & 1.04 & 6.72 & 0.02 & 0.03 & 0.03 & 0.26 & 0.23 \\
\hline 4 & 17.98 & 0.21 & 2.43 & 0.25 & 0.39 & 0.13 & 22.28 & 0.04 & 1.94 & 9.03 & 0.64 & 4.85 & 0.16 & 0.03 & 0.03 & 0.19 & 0.23 \\
\hline 5 & 18.17 & 0.17 & 2.47 & 0.26 & 0.41 & 0.14 & 23.45 & 0.04 & 2.09 & 7.39 & 0.52 & 5.23 & 0.15 & 0.02 & 0.03 & 0.21 & 0.15 \\
\hline 6 & 4.49 & 0.34 & 3.99 & 0.34 & 0.38 & 0.19 & 31.30 & 0.03 & 2.81 & 12.49 & 1.03 & 7.09 & 0.03 & 0.03 & 0.03 & 0.27 & 0.28 \\
\hline 7 & 16.95 & 0.25 & 2.82 & 0.24 & 0.39 & 0.14 & 22.96 & 0.05 & 2.01 & 9.38 & 0.50 & 5.06 & 0.14 & 0.17 & 0.03 & 0.20 & 0.15 \\
\hline 8 & 2.98 & 0.28 & 3.84 & 0.33 & 0.23 & 0.18 & 30.33 & 0.04 & 2.69 & 14.48 & 1.38 & 6.78 & 0.03 & 0.04 & 0.07 & 0.25 & 0.31 \\
\hline 9 & 16.44 & 0.19 & 2.75 & 0.24 & 0.40 & 0.13 & 22.32 & 0.06 & 1.94 & 10.60 & 0.51 & 4.94 & 0.15 & 0.03 & 0.03 & 0.19 & 0.30 \\
\hline 10 & 5.87 & 0.34 & 3.68 & 0.32 & 0.39 & 0.16 & 28.63 & 0.04 & 2.54 & 12.98 & 1.71 & 6.36 & 0.03 & 0.04 & 0.02 & 0.25 & 0.29 \\
\hline
\end{tabular}

Table 7: Chemical trim addition made to runs 1A-10.

\begin{tabular}{|c|c|c|c|c|c|c|c|c|c|c|c|}
\hline $\begin{array}{l}\text { Chemical } \\
\text { Boehmite }\end{array}$ & AlOOH & $\begin{array}{c}\text { 1A } \\
484\end{array}$ & $\begin{array}{c}2 \\
1785\end{array}$ & $\begin{array}{c}3 \\
1907\end{array}$ & $\begin{array}{c}\mathbf{4} \\
0.00\end{array}$ & $\begin{array}{c}\mathbf{5} \\
0.00\end{array}$ & $\begin{array}{c}6 \\
1973\end{array}$ & $\begin{array}{c}7 \\
116\end{array}$ & $\begin{array}{c}\mathbf{8} \\
1498\end{array}$ & $\begin{array}{c}9 \\
133\end{array}$ & $\begin{array}{c}\mathbf{1 0} \\
19.15\end{array}$ \\
\hline Silica & $\mathrm{SiO} 2$ & 1.48 & 1.16 & 1.27 & 1.55 & 1.37 & 1.31 & 1.32 & 0.90 & 1.45 & 1.41 \\
\hline Titania & TiO2 & 0.50 & 0.39 & 0.43 & 0.53 & 0.46 & 0.44 & 0.45 & 0.31 & 0.49 & 0.47 \\
\hline $\begin{array}{l}\text { Sodium } \\
\text { Nitrite } \\
\text { Sodium }\end{array}$ & NaNO2 & 12.58 & 10.42 & 11.15 & 13.74 & 12.19 & 11.42 & 11.72 & 7.97 & 12.86 & 11.88 \\
\hline $\begin{array}{l}\text { Nitrate } \\
\text { Sodium }\end{array}$ & NaNO3 & 7.93 & 6.56 & 7.03 & 8.66 & 7.68 & 7.20 & 7.38 & 5.02 & 8.10 & 7.48 \\
\hline $\begin{array}{l}\text { Sulfate } \\
\text { Sodium }\end{array}$ & $\mathrm{Na} 2 \mathrm{SO} 4$ & 1.35 & 1.12 & 1.19 & 1.47 & 1.31 & 1.22 & 1.25 & 0.85 & 1.38 & 1.27 \\
\hline $\begin{array}{l}\text { Hydroxide } \\
\text { Sodium }\end{array}$ & $\mathrm{NaOH}$ & 6.68 & 5.53 & 5.92 & 7.30 & 6.48 & 6.07 & 6.22 & 4.23 & 6.83 & 6.31 \\
\hline $\begin{array}{l}\text { Carbonate } \\
\text { Sodium }\end{array}$ & Na2CO3 & 2.74 & 2.27 & 2.43 & 2.99 & 2.65 & 2.49 & 2.55 & 1.73 & 2.80 & 2.58 \\
\hline Chloride & $\mathrm{NaCl}$ & 0.15 & 0.13 & 0.14 & 0.17 & 0.15 & 0.14 & 0.14 & 0.10 & 0.16 & 0.15 \\
\hline
\end{tabular}

${ }^{\mathrm{i}}$ The first run is labeled $1 \mathrm{~A}$, as it had to be repeated due to solids settling in the precipitator feed line. The simulant from Run 1 was discarded and not reported in any of the analytical results. 
SRNL-STI-2009-00603

Revision 0

Table 8: Final composition of runs 1A-10.

\begin{tabular}{||c|c|c|c|c|c|c|c|c|c|c||}
\hline & $\mathbf{1 A}$ & $\mathbf{2}$ & $\mathbf{3}$ & $\mathbf{4}$ & $\mathbf{5}$ & $\mathbf{6}$ & $\mathbf{7}$ & $\mathbf{8}$ & $\mathbf{9}$ & $\mathbf{1 0}$ \\
\hline $\mathbf{F e}$ & 14.67 & 14.79 & 14.59 & 15.04 & 15.52 & 14.82 & 15.12 & 14.46 & 14.83 & 14.63 \\
\hline $\mathbf{A l}$ & 11.92 & 12.04 & 11.87 & 12.72 & 12.64 & 12.06 & 12.31 & 11.76 & 12.07 & 11.88 \\
\hline $\mathbf{M n}$ & 7.94 & 5.82 & 6.39 & 6.10 & 4.89 & 5.91 & 6.18 & 6.90 & 7.04 & 6.63 \\
\hline $\mathbf{N i}$ & 3.23 & 3.34 & 3.26 & 3.27 & 3.46 & 3.36 & 3.33 & 3.23 & 3.29 & 3.25 \\
\hline $\mathbf{C a}$ & 1.81 & 1.87 & 1.84 & 1.64 & 1.63 & 1.89 & 1.85 & 1.83 & 1.83 & 1.88 \\
\hline $\mathbf{M g}$ & 1.26 & 1.32 & 1.70 & 1.31 & 1.38 & 1.33 & 1.33 & 1.28 & 1.29 & 1.30 \\
\hline $\mathbf{N a}$ & 12.22 & 12.32 & 12.15 & 12.53 & 12.93 & 12.35 & 12.59 & 12.05 & 12.36 & 12.19 \\
\hline $\mathbf{C r}$ & 0.23 & 0.17 & 0.16 & 0.26 & 0.27 & 0.18 & 0.26 & 0.11 & 0.26 & 0.20 \\
\hline $\mathbf{C e}$ & 0.16 & 0.16 & 0.16 & 0.17 & 0.17 & 0.16 & 0.16 & 0.16 & 0.16 & 0.16 \\
\hline $\mathbf{Z n}$ & 0.13 & 0.13 & 0.13 & 0.13 & 0.14 & 0.13 & 0.13 & 0.12 & 0.13 & 0.13 \\
\hline $\mathbf{B a}$ & 0.21 & 0.07 & 0.10 & 0.14 & 0.11 & 0.16 & 0.16 & 0.13 & 0.13 & 0.17 \\
\hline $\mathbf{P b}$ & 0.10 & 0.02 & 0.01 & 0.11 & 0.10 & 0.01 & 0.09 & 0.01 & 0.10 & 0.01 \\
\hline $\mathbf{Z r}$ & 0.46 & 0.15 & 0.11 & 0.16 & 0.10 & 0.13 & 0.10 & 0.15 & 0.20 & 0.15 \\
\hline $\mathbf{C u}$ & 0.09 & 0.09 & 0.09 & 0.09 & 0.09 & 0.09 & 0.10 & 0.09 & 0.09 & 0.08 \\
\hline $\mathbf{K}$ & 0.05 & 0.00 & 0.03 & 0.03 & 0.03 & 0.02 & 0.03 & 0.02 & 0.04 & 0.02 \\
\hline $\mathbf{S i}$ & 0.65 & 0.66 & 0.64 & 0.67 & 0.69 & 0.66 & 0.67 & 0.64 & 0.66 & 0.65 \\
\hline $\mathbf{S}$ & 0.02 & 0.02 & 0.02 & 0.02 & 0.02 & 0.02 & 0.11 & 0.02 & 0.02 & 0.02 \\
\hline $\mathbf{T i}$ & 0.28 & 0.28 & 0.27 & 0.28 & 0.29 & 0.28 & 0.28 & 0.27 & 0.28 & 0.28 \\
\hline
\end{tabular}

\subsection{Particle size}

The CSTR parameters were set up in such a way as to ensure the formation of a range of particle sizes. It was assumed that particle size would be a major contributing factor to the settling rate and rheology of the simulant. Therefore, being able to directly control the particle size of the simulant would allow better control of the rheological properties of the simulant. The results of the particle size analysis, performed by $\mathrm{AD}$, can be seen in Table 9. Runs 5 and 7 showed a bimodal particle size distribution. It is not certain which parameter changes, if any, result in the bimodal distribution. One physical interpretation is that they represent the product of a nonhomogeneous precipitating system [9]. 
Table 9: Results of particle size analysis

\begin{tabular}{||c|c||}
\hline Run & $\begin{array}{c}\text { Volume Mean } \\
\text { Diameter }(\boldsymbol{\mu m})\end{array}$ \\
\hline $1 \mathrm{~A}$ & 22.3 \\
\hline 2 & 31.9 \\
\hline 3 & 31.5 \\
\hline 4 & 22.9 \\
\hline 5 & $3.1,24.8$ \\
\hline 6 & 38.2 \\
\hline 7 & 3.8 .17 .1 \\
\hline 8 & 24.6 \\
\hline 9 & 11.1 \\
\hline 10 & 31.5 \\
\hline
\end{tabular}

Particle size distributions were consistent with that which has been seen in previous studies $[1,6]$. A representation of a typical distribution seen for this set of experiments is presented in Figure 2. Particle sizes based on mean volume diameters for batches $1 \mathrm{~A}-10$ are presented in Figure 3 . Distributions for all runs are located in Appendix A, Exhibit A-1.

Figure 2: Mean volume distribution for SB6A batch 1A.

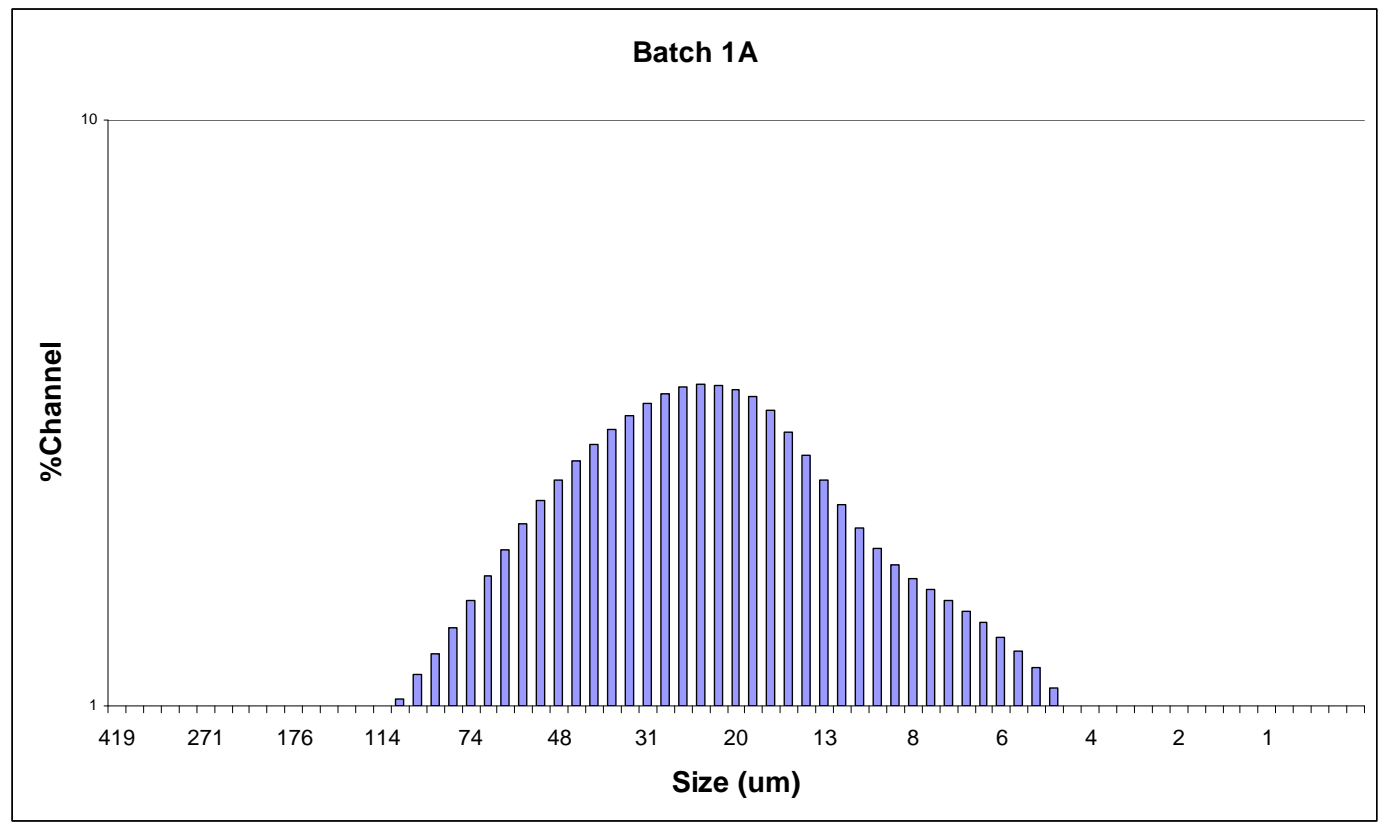


Figure 3: Mean particle size for SB6A simulant batches.

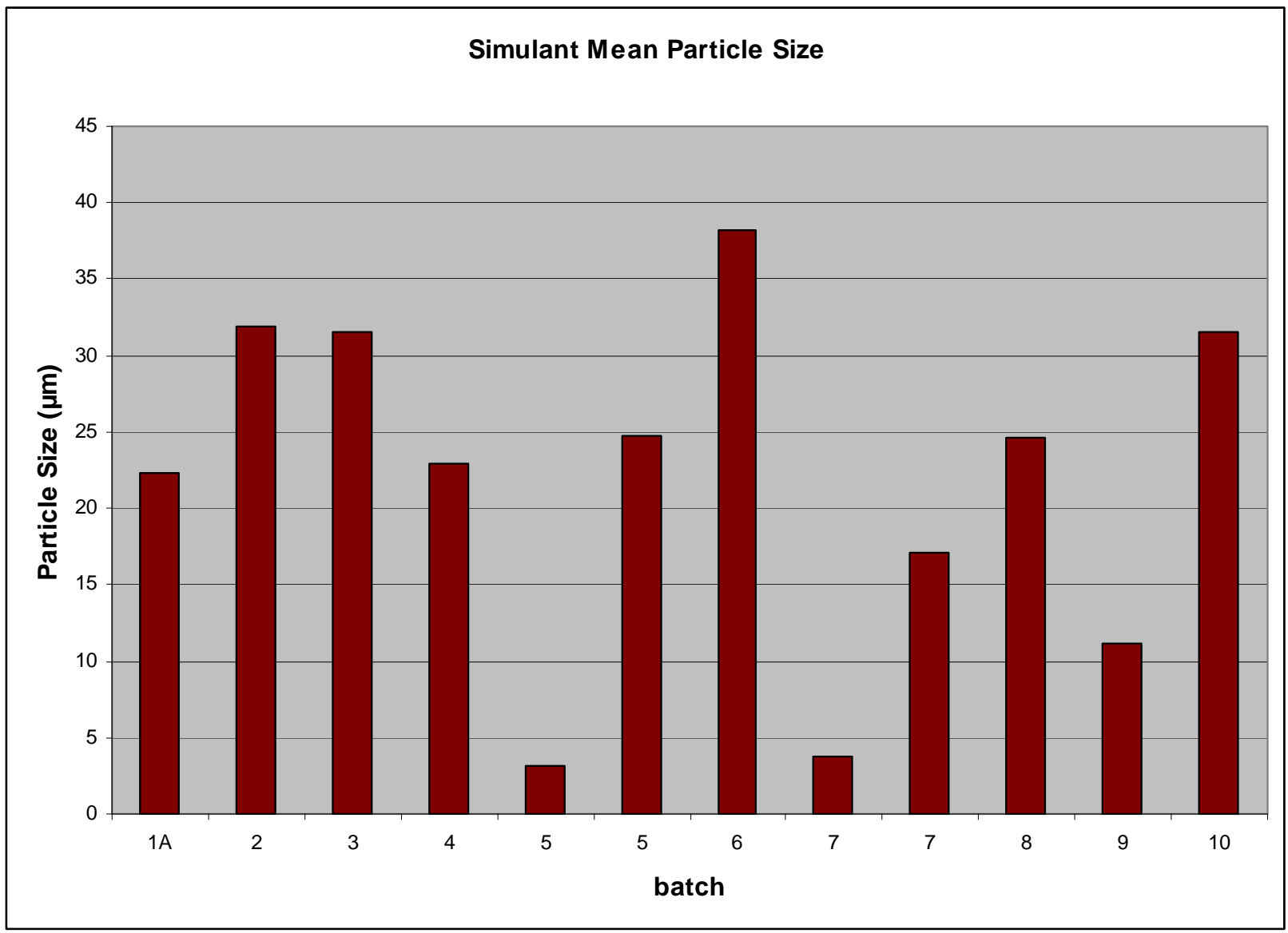

An analysis of the parametric factors affecting particle size was performed using JMP statistical software [7]. The results of that analysis indicate that $\mathrm{pH}$, flow rate, and mixing speed were factors that contributed, to some degree, to the simulant particle size. Of the parameters tested, temperature seemed to have smallest, or no impact. The analytical output provided equations that show the relative effect of each contributing parametric factor and the degree of accuracy with which one could predictably target desired particle sizes (Figure 4). 
SRNL-STI-2009-00603

Revision 0

Figure 4: JMP software analysis of parametric effect on particle size.

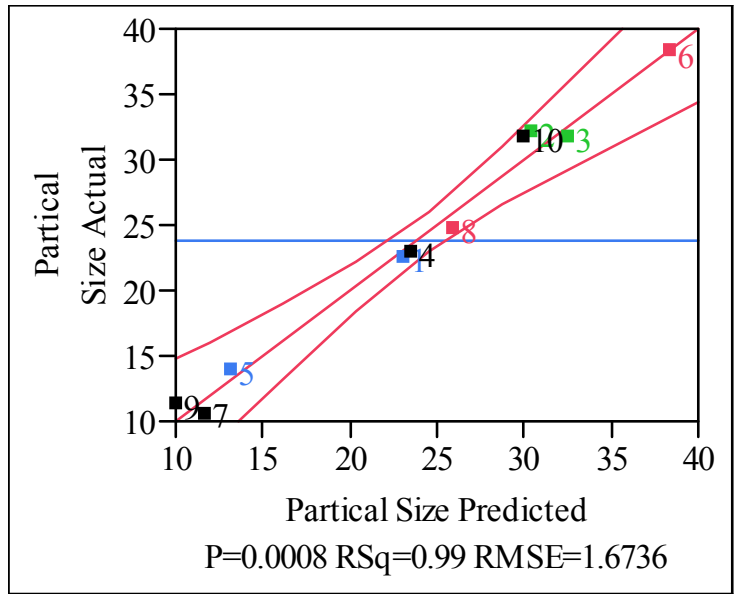

Summary of Fit

$\begin{array}{lr}\text { RSquare } & 0.986562 \\ \text { RSquare Adj } & 0.969764 \\ \text { Root Mean Square Error } & 1.67363 \\ \text { Mean of Response } & 23.83 \\ \text { Observations (or Sum Wgts) } & 10\end{array}$

Analysis of Variance

Source DF Sum of Squares Mean Square F Ratio

$\begin{array}{lllll}\text { Model } & 5 & 822.55185 & 164.510 & 58.7320\end{array}$

$\begin{array}{llll}\text { Error } & 4 & 11.20415 & 2.801 \text { Prob }>\text { F }\end{array}$

$\begin{array}{llll}\text { C. Total } 9 & 833.75600 & 0.0008\end{array}$

Parameter Estimates

Term

Intercept

Actual pH

flow rate $(\mathrm{ml} / \mathrm{min})$

mixing speed (rpm)

(Actual pH-12.463)*(Actual pH-12.463)

(Actual pH-12.463)*(mixing speed (rpm)-650)

$\begin{array}{rrrr}\text { Estimate } & \text { Std Error } & \text { t Ratio } & \text { Prob }>|\mathbf{t}| \\ -61.19439 & 5.983634 & -10.23 & 0.0005 \\ 6.4095057 & 0.416364 & 15.39 & 0.0001 \\ 0.0288282 & 0.005556 & 5.19 & 0.0066 \\ -0.011146 & 0.001809 & -6.16 & 0.0035 \\ 2.2513661 & 0.227186 & 9.91 & 0.0006 \\ -0.003204 & 0.00094 & -3.41 & 0.0271\end{array}$

As can be seen in Figure 4, the data show a good fit for predicted versus actual particle size with an $\mathrm{R}^{2}$ value of 0.99 . Parametric estimates shows the degree to which each contributing parameter affects the particle size. Of those parameters, it appears as though $\mathrm{pH}$ has the largest effect. When one looks solely at the effect of $\mathrm{pH}$, the quadratic presented in Figure 5 is seen which shows the dependence of $\mathrm{pH}$ on simulant particle size. 
Figure 5: JMP software analysis of the effect of $\mathrm{pH}$ on simulant particle size.

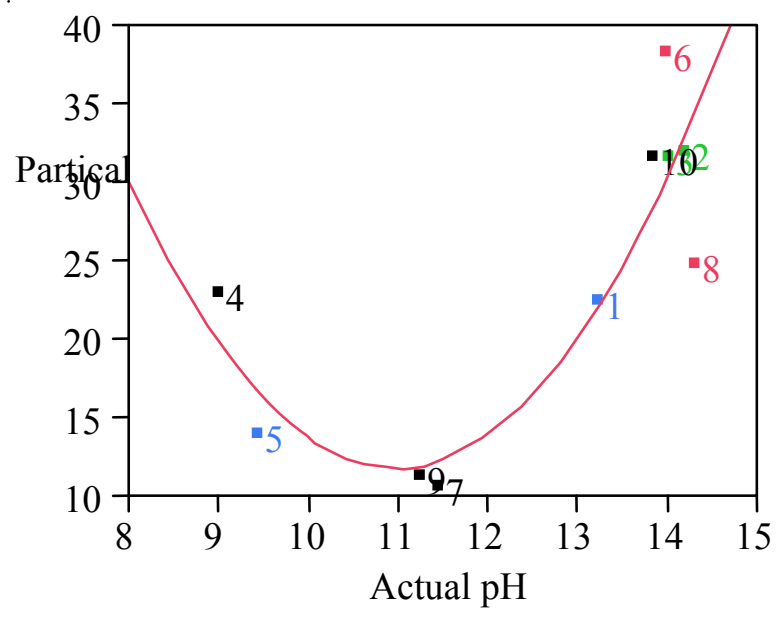

Polynomial Fit Degree=2

Polynomial Fit Degree $=2$

Partical Size $=-59.25008+6.0550294 *$ Actual $\mathrm{pH}+2.0454203 *(\text { Actual } \mathrm{pH}-12.463)^{\wedge} 2$

Summary of Fit

$\begin{array}{lr}\text { RSquare } & 0.766863 \\ \text { RSquare Adj } & 0.700253 \\ \text { Root Mean Square Error } & 5.269579 \\ \text { Mean of Response } & 23.83 \\ \text { Observations (or Sum Wgts) } & 10\end{array}$

Analysis of Variance

Source DF Sum of Squares Mean Square F Ratio

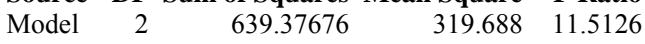

$\begin{array}{llll}\text { Error } & 7 & 194.37924 & 27.768 \text { Prob }>\text { F }\end{array}$

$\begin{array}{llrr}\text { C. Total } 9 & 833.75600 & 0.0061\end{array}$

Parameter Estimates

Term

Estimate Std Error t Ratio Prob $>|\mathbf{t}|$

Intercept

$\begin{array}{llll}-59.25008 & 17.96978 & -3.30 & 0.0132\end{array}$

$\begin{array}{lllll}\text { Actual pH } & 6.0550294 & 1.277852 & 4.74 & 0.0021\end{array}$

$\begin{array}{lllll}(\text { Actual pH-12.463)^2 } & 2.0454203 & 0.686074 & 2.98 & 0.0205\end{array}$ 


\subsection{Simulant Settling}

SB6A simulant batches $1-10$ were allowed to settle over a period of several days. Photos of the degree of settling are presented in Figure 6 and Figure 7. From visual inspection of the settled simulants, it can be seen that the more settled batches $(6,8,3,2)$ were obtained at high $\mathrm{pH}$, while the less settled batches $(4,10,5,9,1,7)$ were from lower pHs. Ideally, one would expect to see a more settled simulant resulting for those containing larger particle sizes. This was not consistent with the tested simulant batches in this study.

Figure 6: Degree of settling for SB6A batches 1-5.

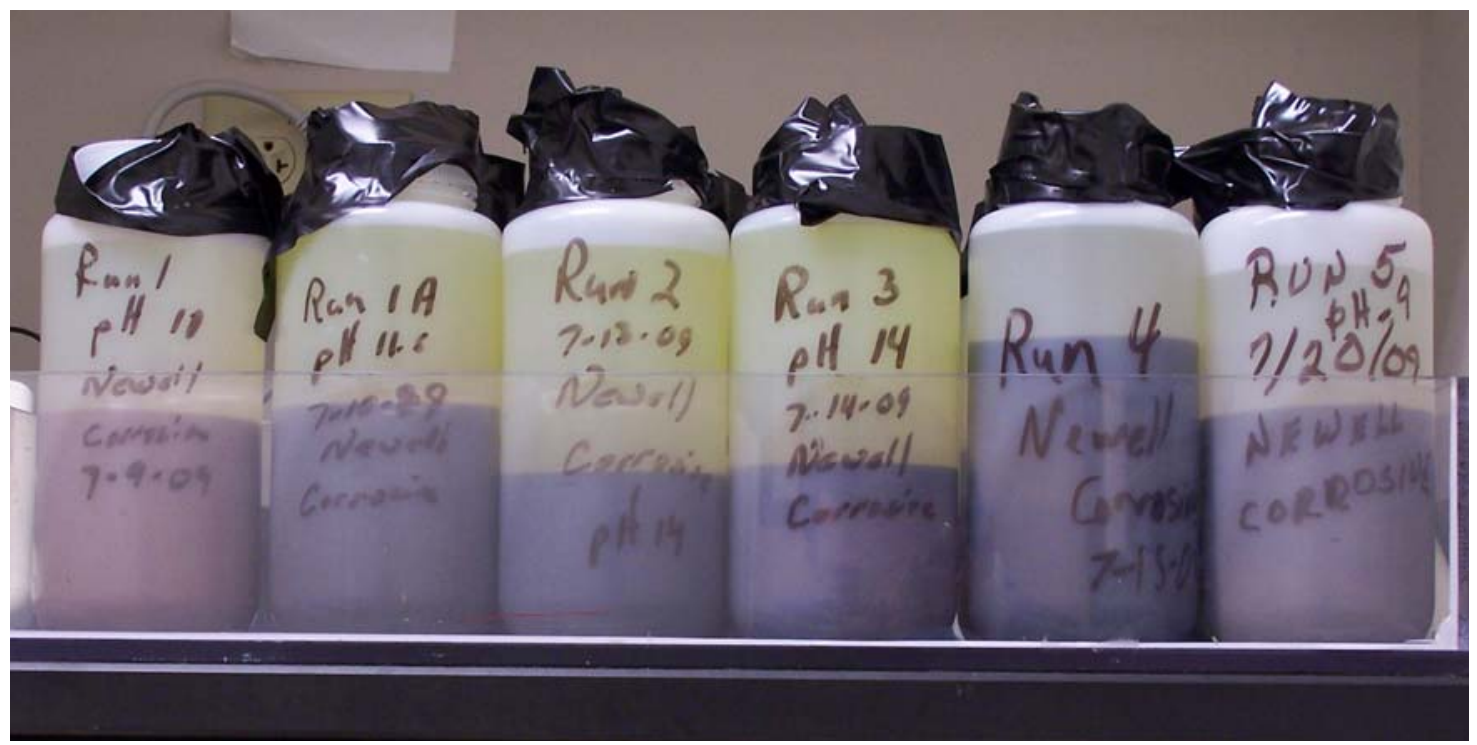

Figure 7: Degree of settling for SB6A batches 6-10.

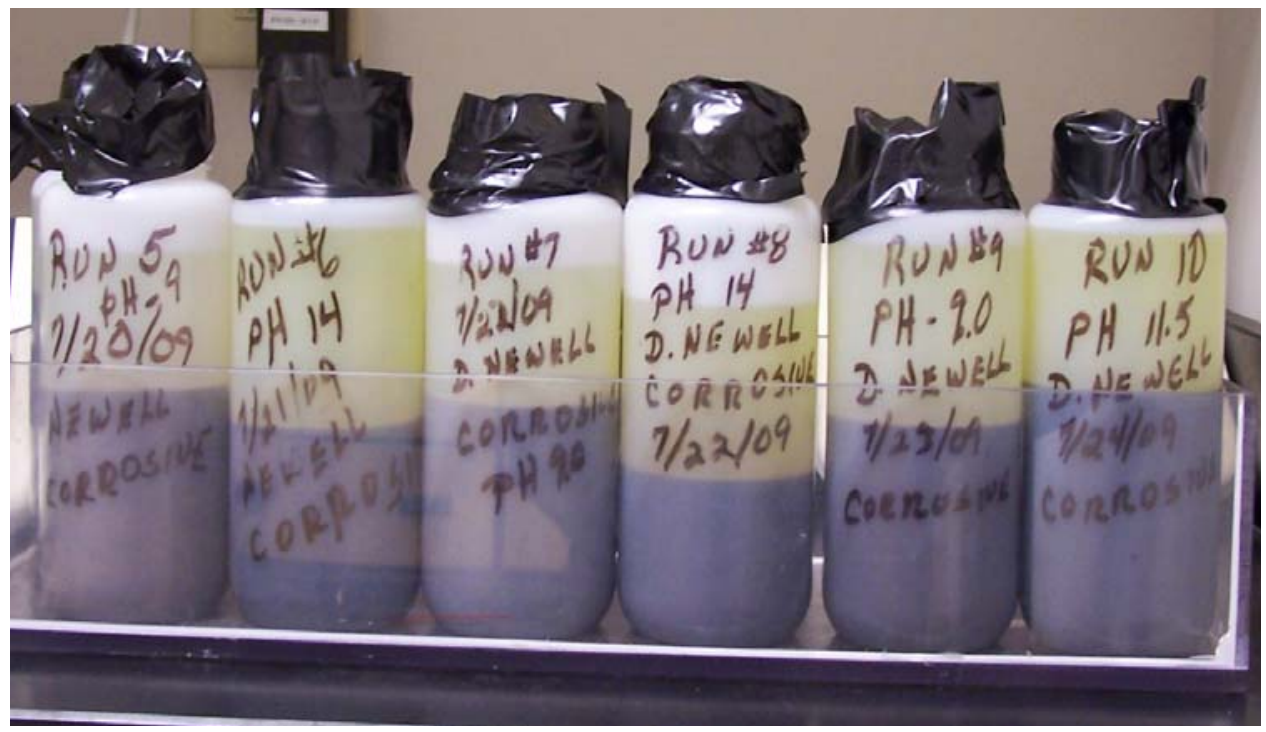




\subsection{Rheology}

The rheology of the SB6A simulant batches was measured using a rotational Haake rheometer at three different wt.\% insoluble solids (Figure 8). The observed trend was expected, seeing an increase in yield stress with increasing levels of insoluble solids [8].

Figure 8: Yield stress summary of SB6A simulant batches 1-10, relative to wt.\% insoluble solids

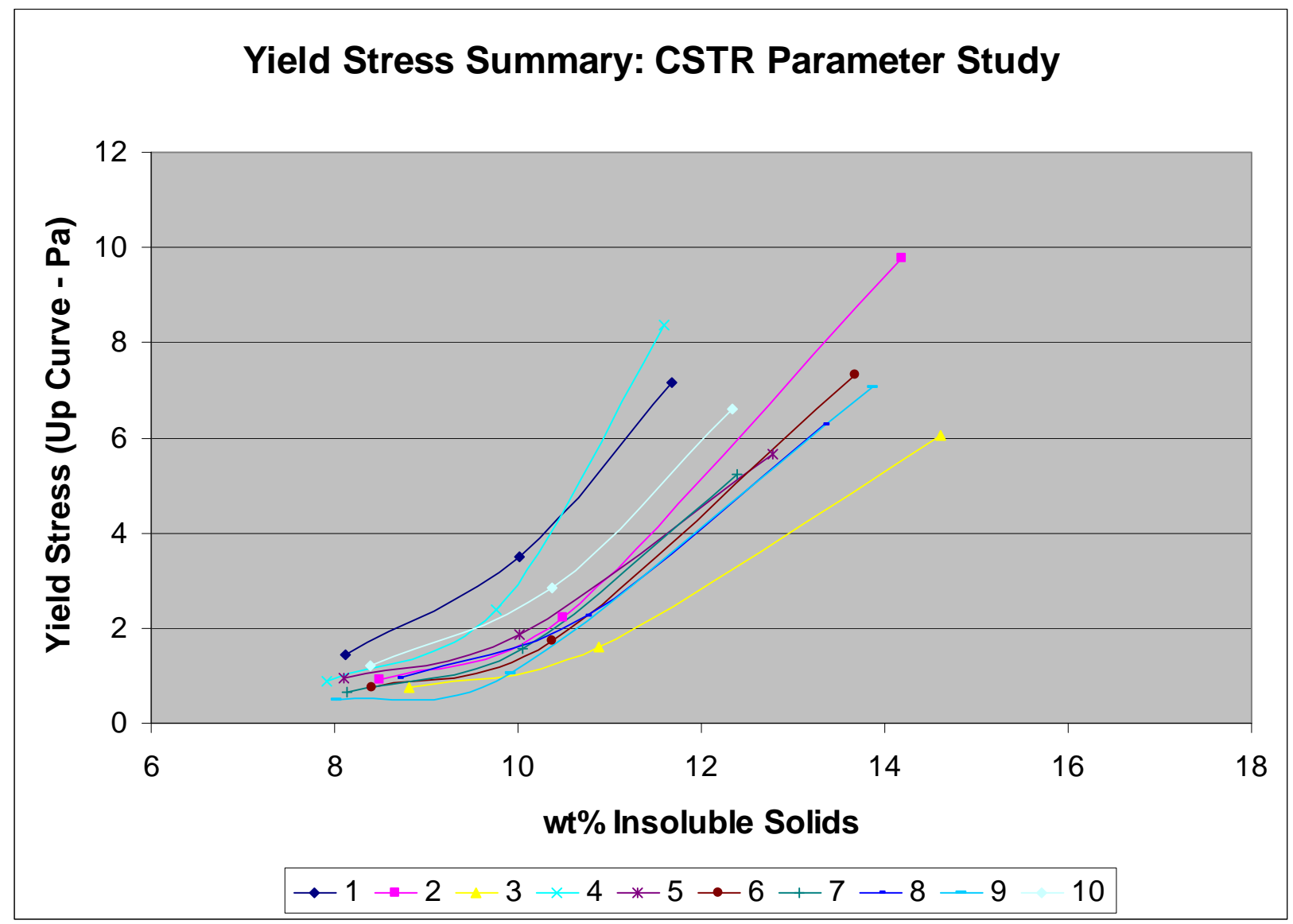

When yield stress is examined with respect to the effect of varying the parametric values, it is seen that $\mathrm{pH}$, flow rate, temperature and mixing speed all have a linear effect (Figure 9). The data show a strong correlation between the predicted and actual yield stress with an $\mathrm{R}^{2}$ value of 0.97 , with the exception of batch 10 . For all of the batches, the up curve yield stresses were higher than the down curve yield stresses. Summary and detailed rheology data is found in Appendix A, Exhibit A-2. 
SRNL-STI-2009-00603

Revision 0

Figure 9: JMP software analysis of parametric effect on rheology

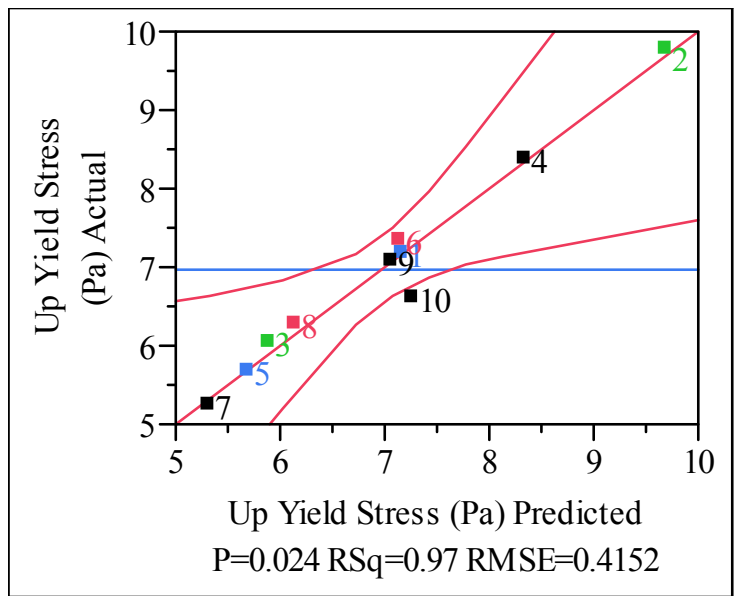

Summary of Fit

$\begin{array}{lr}\text { RSquare } & 0.968091 \\ \text { RSquare Adj } & 0.904274 \\ \text { Root Mean Square Error } & 0.415199 \\ \text { Mean of Response } & 6.953 \\ \text { Observations (or Sum Wgts) } & 10\end{array}$

Analysis of Variance

Source DF Sum of Squares Mean Square F Ratio

$\begin{array}{lllll}\text { Model } & 6 & 15.690639 & 2.61511 & 15.1697\end{array}$

$\begin{array}{llll}\text { Error } & 3 & 0.517171 & 0.17239 \text { Prob }>\text { F }\end{array}$

$\begin{array}{llrl}\text { C. Total } 9 & 16.207810 & 0.0240\end{array}$

Parameter Estimates

Term

Intercept

Actual pH

flow rate $(\mathrm{ml} / \mathrm{min})$

temperature $\left({ }^{\circ} \mathrm{C}\right)$

mixing speed (rpm)

(flow rate $(\mathrm{ml} / \mathrm{min})-140) *\left(\right.$ temperature $\left.\left({ }^{\circ} \mathrm{C}\right)-46\right)$

(temperature $\left.\left({ }^{\circ} \mathrm{C}\right)-46\right) *($ mixing speed $(\mathrm{rpm})-650)$

$\begin{array}{rrrr}\text { Estimate } & \text { Std Error } & \text { t Ratio } & \text { Prob }>|\mathbf{t}| \\ 5.530639 & 0.926903 & 5.97 & 0.0094 \\ 0.1608891 & 0.070377 & 2.29 & 0.1063 \\ 0.0065354 & 0.001335 & 4.90 & 0.0163 \\ -0.022687 & 0.006341 & -3.58 & 0.0373 \\ -0.000699 & 0.000445 & -1.57 & 0.2146 \\ -0.000342 & 5.561 \mathrm{e}-5 & -6.16 & 0.0086 \\ -6.224 \mathrm{e}-5 & 1.882 \mathrm{e}-5 & -3.31 & 0.0455\end{array}$

\subsection{Foaming}

Part of the simulant development program involves testing the effect of differing sludge simulant formulation parameters on foaming behavior. Procedure ITS-0142 was used with a supplemental R\&D Direction, SRNL-L3100-2009-00211. For each test, an antifoam test apparatus was charged with $300 \mathrm{~mL}$ of sludge. Antifoam was available but was not needed. The boilup rate was $0.8 \mathrm{~g} / \mathrm{min}$ with a hot plate setting of $450^{\circ} \mathrm{C}$ during the initial heat-up phase and $400^{\circ} \mathrm{C}$ at steady state; the sludge boiled at $100-101^{\circ} \mathrm{C}$. The boiling was conducted under reflux conditions for 60 to 80 minutes before shutdown. Mercury was not present in the sludges. The extent of foaming on the 10 simulants is documented in Table 10 The plots of the average and maximum foam heights (normalized by mass), reveals only a very weak positive dependence of foam height with mixing speed during precipitation. For Figure 11; the slope is approximately $0.04 \mathrm{~mL} / \mathrm{rpm}$. Figure 12 through Figure 14 reveal no dependence on $\mathrm{pH}$, flow rate, and temperature. Since 
foaming was mild, foaming rises of 30 to $90 \mathrm{~mL}$ (avg and peak values, respectively), antifoam was not needed. There was no correlation of foam height relative to particle size (Figure 10).

Figure 10: Foaming height versus particle size distribution

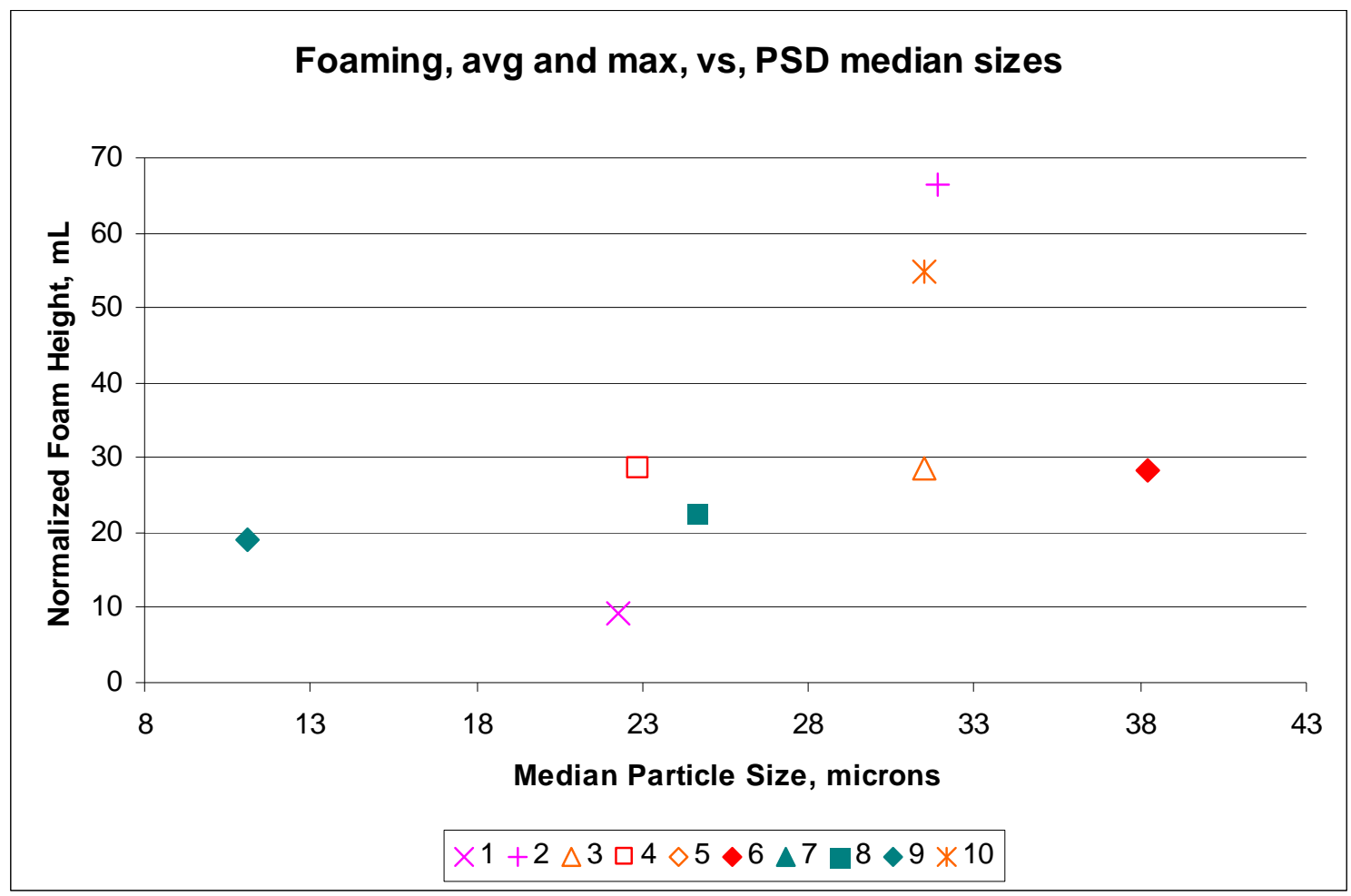


Table 10: CSTR sludge formulation parameters

\begin{tabular}{||c|c|c|c|c||}
\hline \hline Run $^{\text {a }}$ & mass, g & $\begin{array}{c}\text { Cold hgt } \\
\text { start }^{\mathbf{b}}\end{array}$ & $\begin{array}{c}\text { Total hgt } \\
\text { avg/max }\end{array}$ & $\begin{array}{c}\text { Foam hgt } \\
\text { avg/max }^{\mathbf{c}}\end{array}$ \\
\hline $1 \mathrm{~A}^{\mathrm{d}}$ & 320.4 & $310 \mathrm{~mL}$ & $320 / 380 \mathrm{~mL}$ & $10 / 70$ \\
\hline $2^{\mathrm{e}}$ & 316.4 & $310 \mathrm{~mL}$ & $380 / 400 \mathrm{~mL}$ & $70 / 90$ \\
\hline $3^{\mathrm{e}}$ & 315.9 & $310 \mathrm{~mL}$ & $340 / 340 \mathrm{~mL}$ & $30 / 30$ \\
\hline $4^{\mathrm{f}}$ & 316.2 & $310 \mathrm{~mL}$ & $340 / 360 \mathrm{~mL}$ & $30 / 50$ \\
\hline $5^{\text {e }}$ & 316.0 & $310 \mathrm{~mL}$ & $360 / 380 \mathrm{~mL}$ & $50 / 70$ \\
\hline $6^{\mathrm{e}, \mathrm{f}}$ & 319.6 & $310 \mathrm{~mL}$ & $340 / 380 \mathrm{~mL}$ & $30 / 70$ \\
\hline $7^{\mathrm{d}, \mathrm{g}}$ & 323.7 & $310 \mathrm{~mL}$ & $380 / 400 \mathrm{~mL}$ & $70 / 90$ \\
\hline $8^{\mathrm{d}, \mathrm{g}}$ & 264.6 & $280 \mathrm{~mL}$ & $300 / 340 \mathrm{~mL}$ & $20 / 60$ \\
\hline $9^{\mathrm{d}, \mathrm{h}}$ & 314.6 & $320 \mathrm{~mL}$ & $340 / 400 \mathrm{~mL}$ & $20 / 80$ \\
\hline $10^{\mathrm{i}}$ & 274.1 & $300 \mathrm{~mL}$ & $350 / 380 \mathrm{~mL}$ & $50 / 80$ \\
\hline
\end{tabular}

Where,

a) caustic boiling from 60 to 80 minutes, $\mathrm{T}=101^{\circ} \mathrm{C}, 250 \mathrm{rpm}$ stirring, fill to $\sim 300 \mathrm{~mL}$ in $4 \mathrm{~L}$ rig

b) height of vortex using mixer at $250 \mathrm{rpm}$, room temperature

c) difference of total height (with foam) and cold, non-foam sludge yields only the foam height

d) small and large bubbles, on sides and near shaft, respectively

e) small bubbles (mostly), on sides and near shaft, respectively

f) frothy across the entire surface

g) small amount of whitish foam

h) tan color around the shaft at $78^{\circ} \mathrm{C}$ (during the heating phase, as opposed to cooling/shutdown)

i) small and large bubbles mostly on side

Figure 11: Foaming height (average and maximum) vs. mixing speed

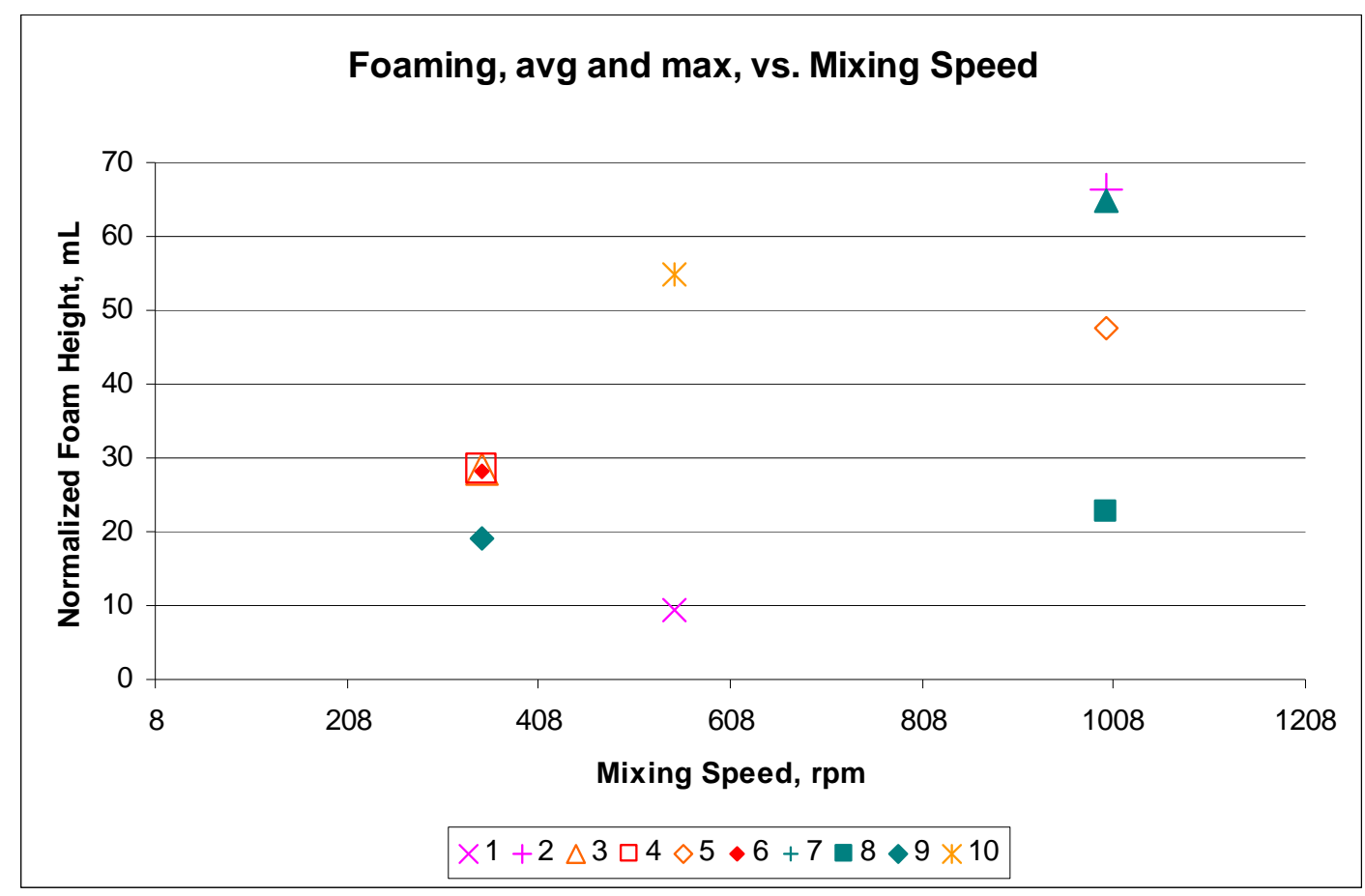


Figure 12: Foaming height (average and maximum) vs. pH

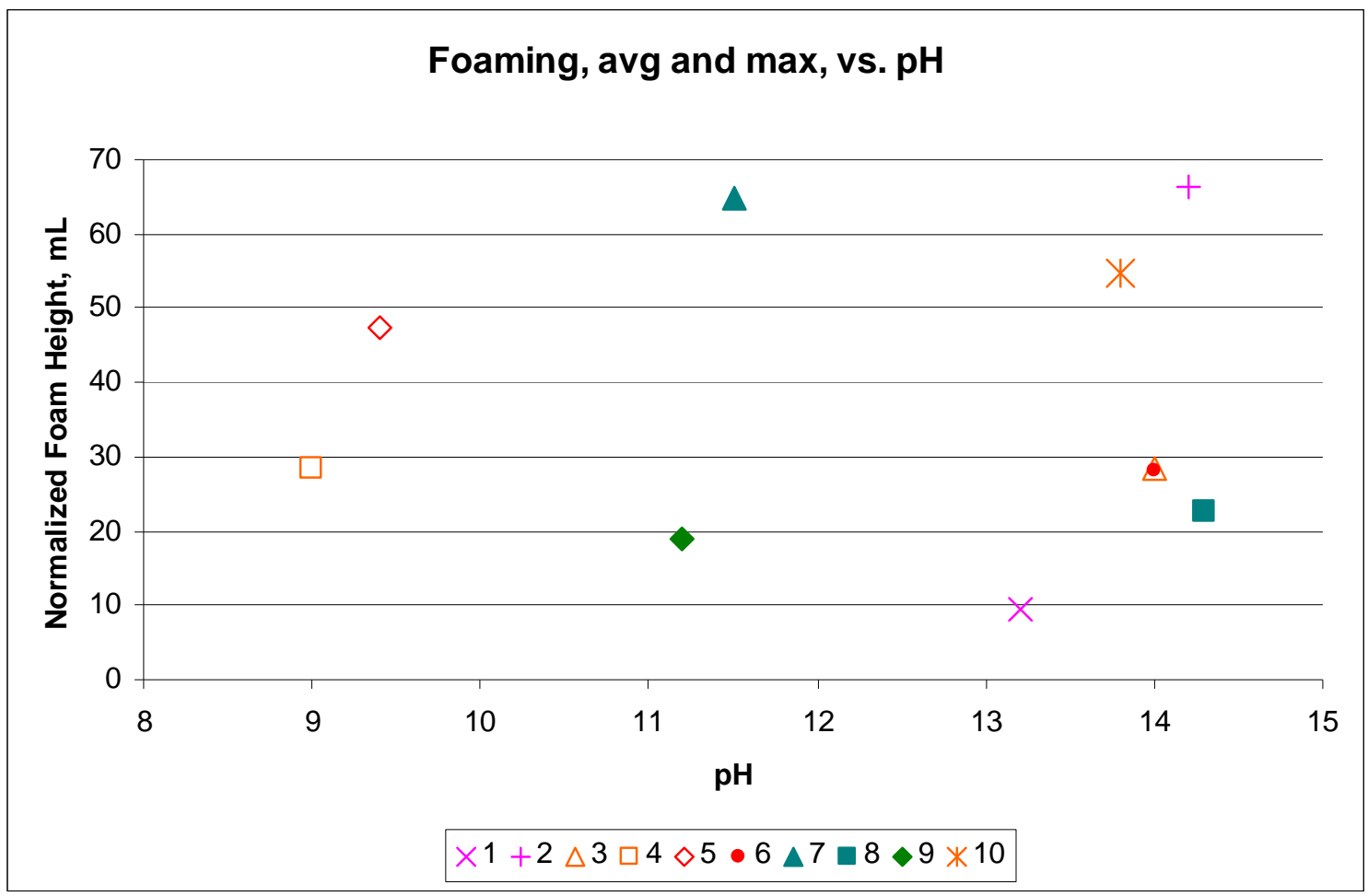

Figure 13: Foaming height (average and maximum) vs. flow rate

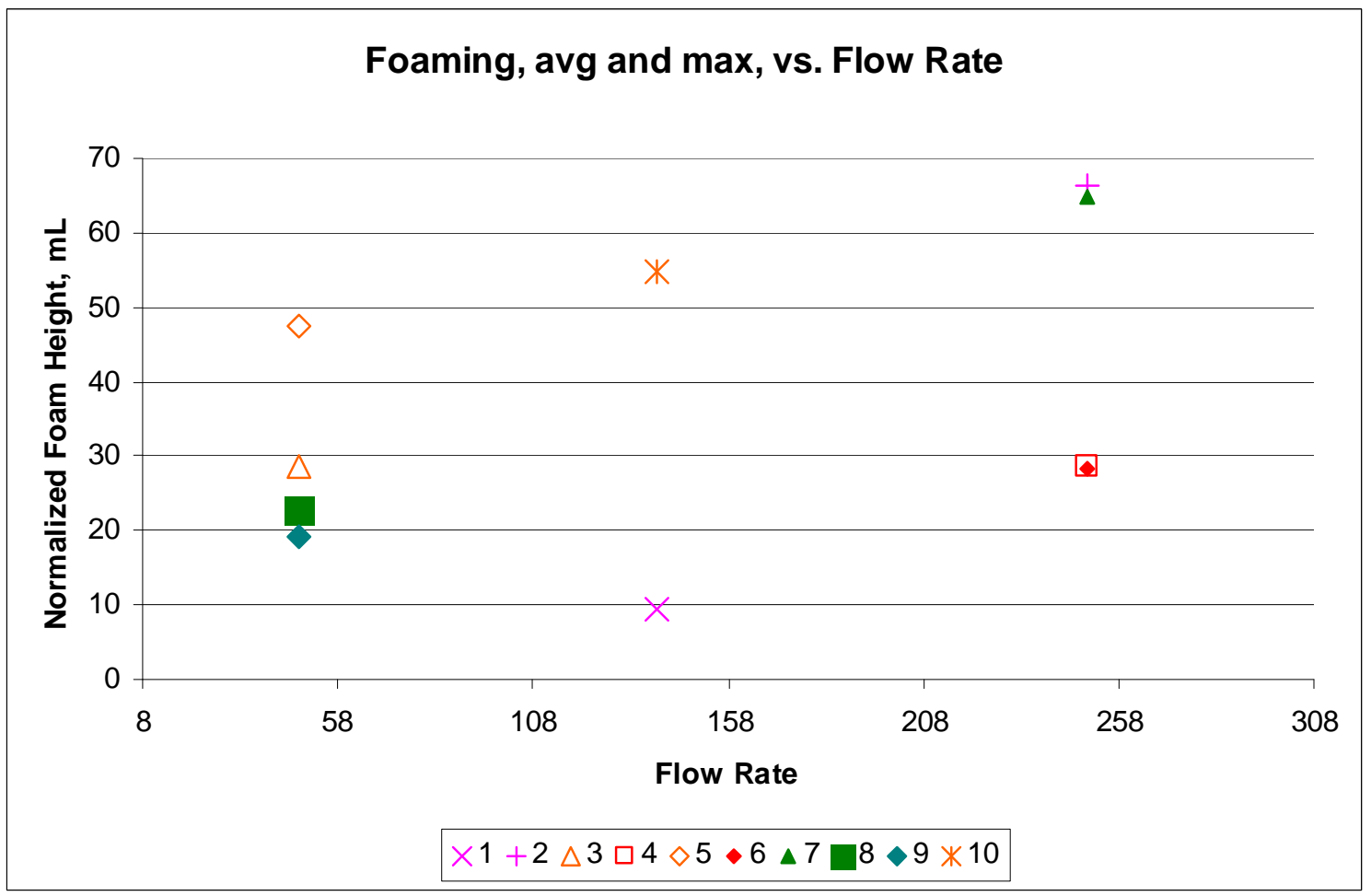


Figure 14: Foaming height (average and maximum) vs. temperature

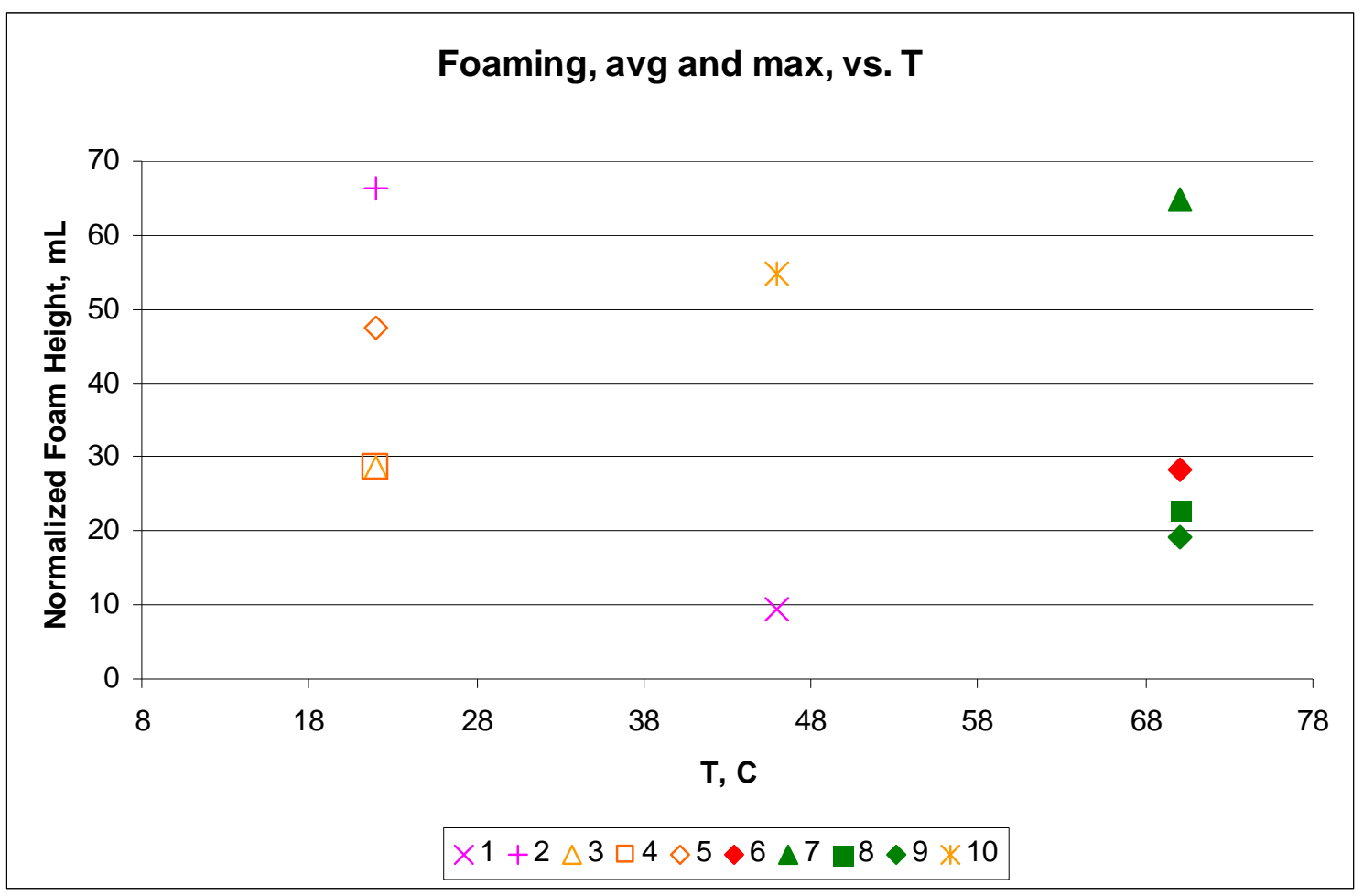




\subsection{Conclusions}

Historically, it has been seen that significant differences in the physical properties of simulated wastes are observed depending on the preparation route selected. The focus of this research was to look at which parameters would have an effect on the simulant properties of particle size, rheology, and foaming using the CSTR preparation method in order to make a sludge simulant that is more prototypical of Savannah River Site sludge. Each of these properties has an important impact on DWPF waste processing, and as such there is a need to be able to correctly simulate these properties of actual waste sludge.

By changing the values for $\mathrm{pH}$, temperature, flow rate, and mixing for sludge slurry precipitations the following observations were made:

\section{Particle Size}

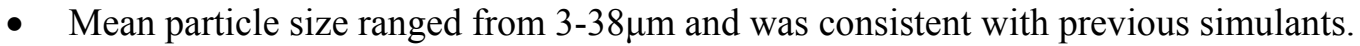

- Changes in $\mathrm{pH}$, flow rate, and mixing speed are statistically significant with respect to particle size.

- The effect of flow rate and mixing speed are linear while that of $\mathrm{pH}$ is quadratic. Results indicated that a lower $\mathrm{pH}$ produces smaller particles.

Rheology

- Increasing wt.\% insoluble solids increases yield stress, as expected.

- Changes in $\mathrm{pH}$, flow rate, temperature, and mixing speed are statistically significant with respect to yield stress.

- The effects of the tested parameters are linear.

- By varying the parameters tested, it appears that simulant yield stress could be adjusted to a targeted value.

Foaming

- Increasing mixing speed had a slight effect on increasing simulant foaming.

- Changes in $\mathrm{pH}$, flow rate, and temperature had no effect on foaming.

\subsection{Recommendations}

The work performed for this study looked at four parametric effects for simulant SB6A. This resulted in 10 distinct batches for analysis. This was the least number of batches that could be prepared and still have the statistical ability to determine the individual effects of these parameters, if any, on the physical properties of simulant particle size, rheology, and foaming. For a more accurate correlation of the influence of these parameters, 10 additional batches would need to be prepared and tested. The results presented in this report are only for the simulant tested, SB6A. It is not known what effect, if any, differences in sludge composition will have on the results of this parametric study. Additional testing of sludge batches of varying composition would identify compositional effects on the physical properties investigated.

Although conclusions can be drawn that several parameters had an effect on the physical properties of the tested simulant (i.e. the effect of $\mathrm{pH}$ on particle size), none of the parameters tested led to a simulant that foamed consistent with sludge foaming under caustic boiling, as seen with the real sludge. SRNL is currently partnering with foam experts at the Illinois Institute of 
SRNL-STI-2009-00603

Revision 0

Technology (IIT). IIT will perform a study on simulants provided to them by SRNL. Their recommendations will be incorporated into a future test program. 


\subsection{References}

1. R.E. Eibling, "Impact of Simulant Production Methods on the Physical Properties of DWPF Sludge Batch 3 Simulant", WSRC-TR-2004-00578.

2. D.C. Koopman, "Rheology Improvements During Preparation of 40-Inch Heel Case Simulants for Sludge Batch 4", WSRC-STI-2006-00067.

3. J.D. Newell, "SB6-A Simulant Development", SRNL-3100-2009-00069.

4. D.D. Larsen, "Sludge Batch 6 Projected Batch and Blend Compositions", LWO-LWP-200900001 .

5. J.D. Newell, "Run Plan for Continuously Stirred Tank Reactor (CSTR) Parametric Study", SRNL-L3100-2009-00147.

6. D.P. Lambert, "Impact of Simulant Production Methods on SRAT Product", WSRC-TR2005-00294.

7. JMP $^{\mathrm{TM}}$, Version 7.0.2, SAS Institute Inc., Cary, NC, 1989-2007.

8. R.E. Eibling, "Impact of Irradiation and Thermal Aging on DWPF Simulated Sludge Properties", WSRC-TR-2005-00543.

9. D.C. Koopman, "Impact of Preparation Methods and Scale Factors on Sludge Batch 4 Simulant Properties, WSRC-STI-2006-00088. 
SRNL-STI-2009-00603

Revision 0

Appendix A 
Exhibit A-1: Mean volume distributions for batches 1A-10
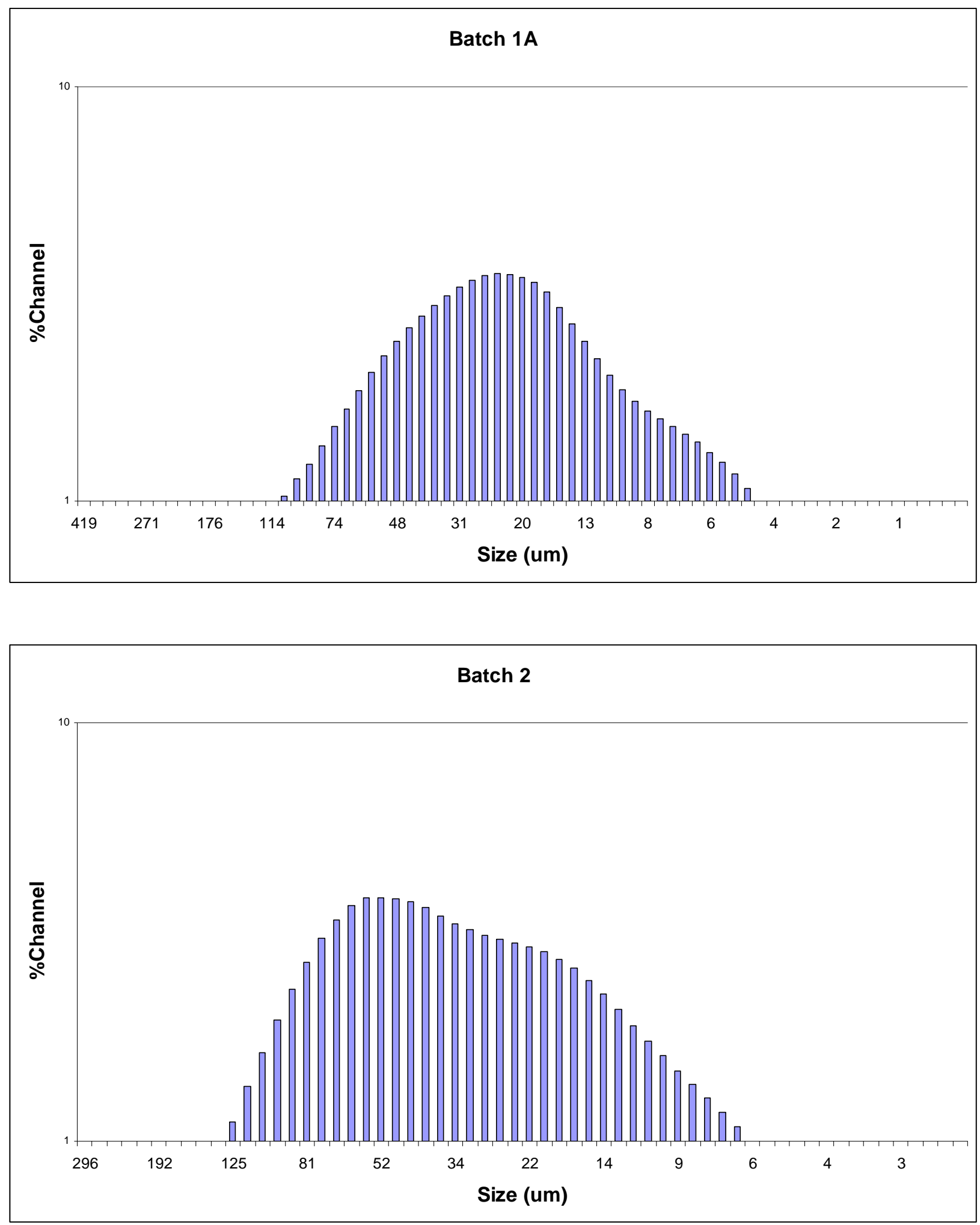
Exhibit A-1: Mean volume distributions for batches 1A-10 (cont.)
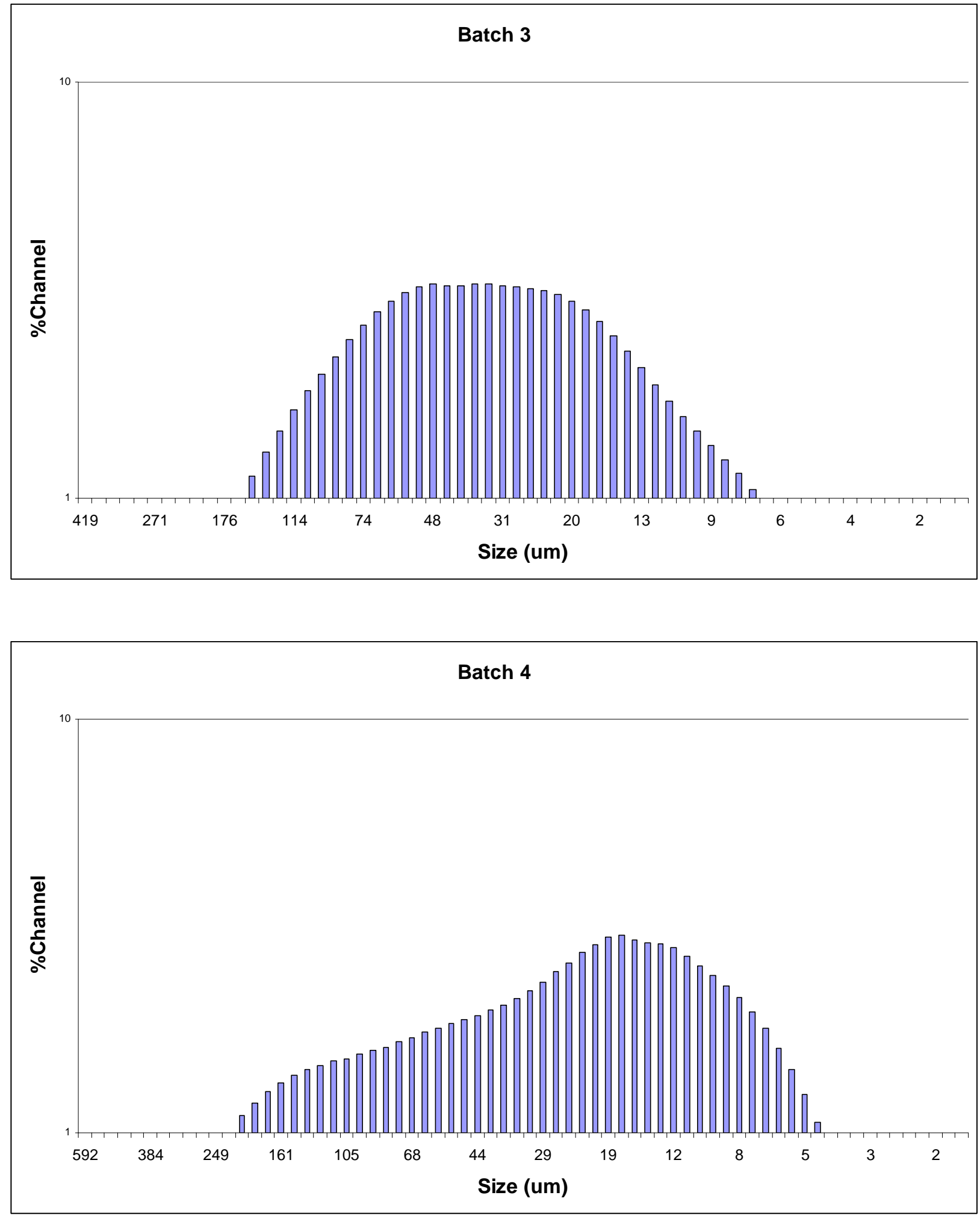
Exhibit A-1: Mean volume distributions for batches 1A-10 (cont.)
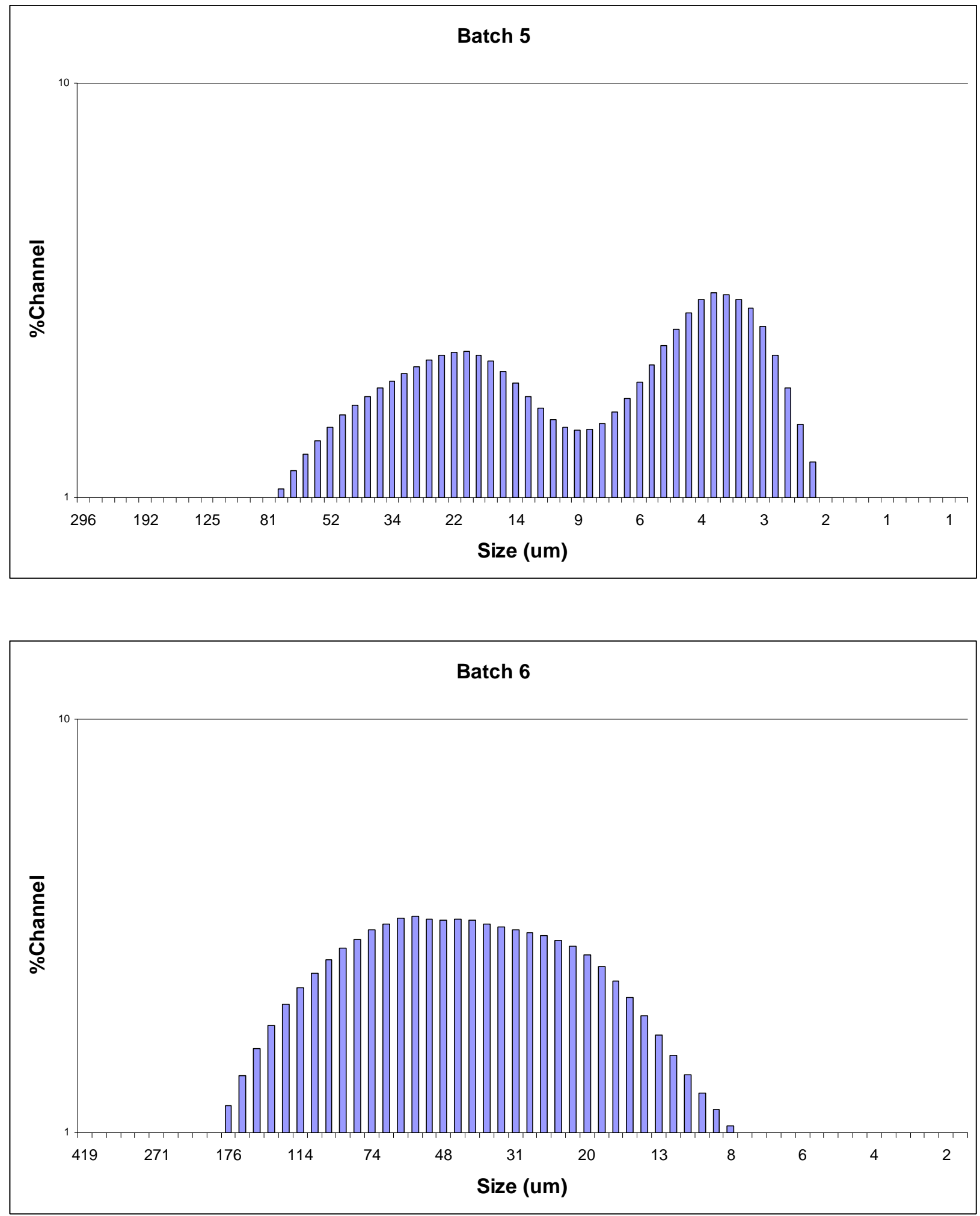
Exhibit A-1: Mean volume distributions for batches 1A-10 (cont.)

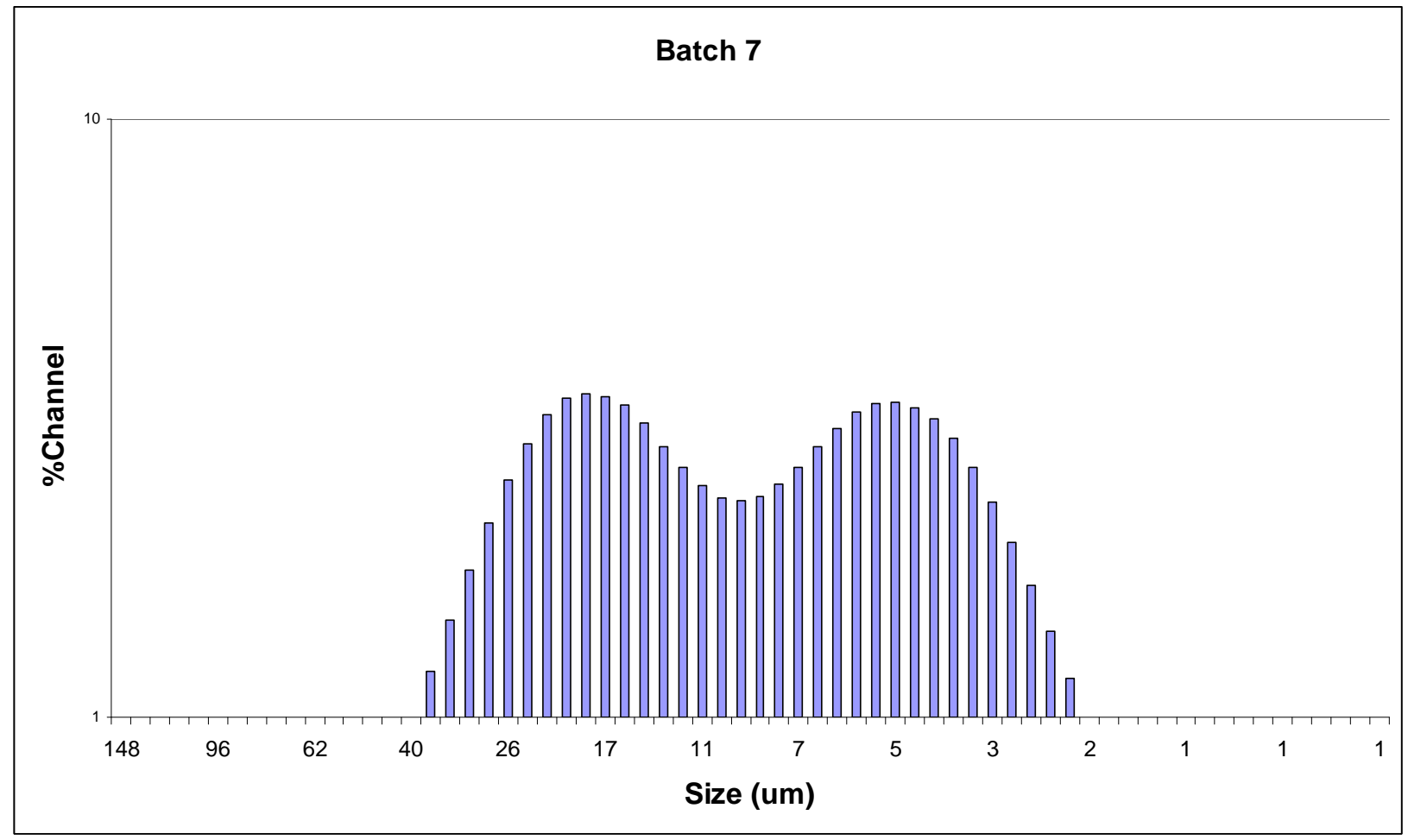

Batch 8

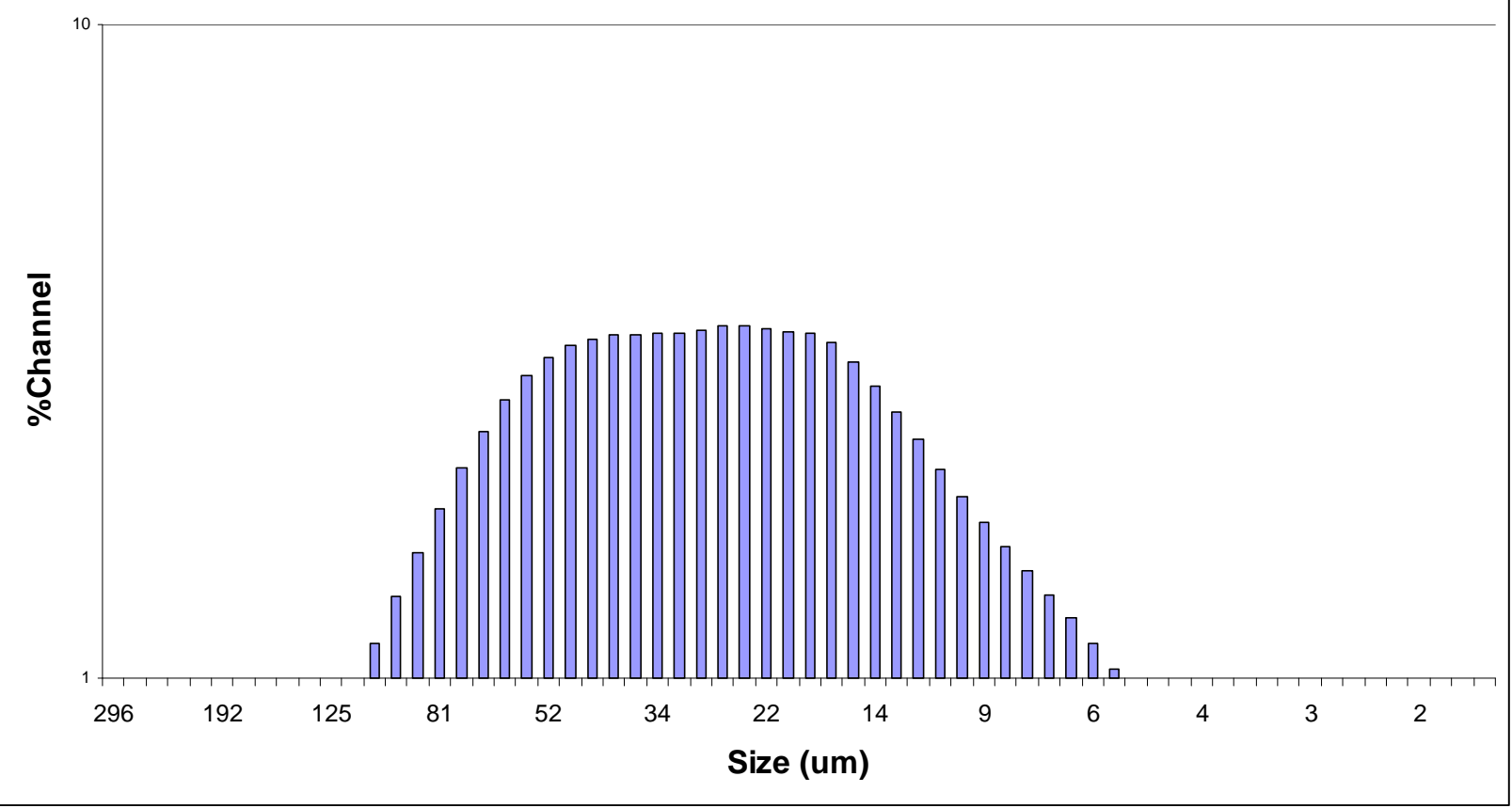


Exhibit A-1: Mean volume distributions for batches 1A-10 (cont.)

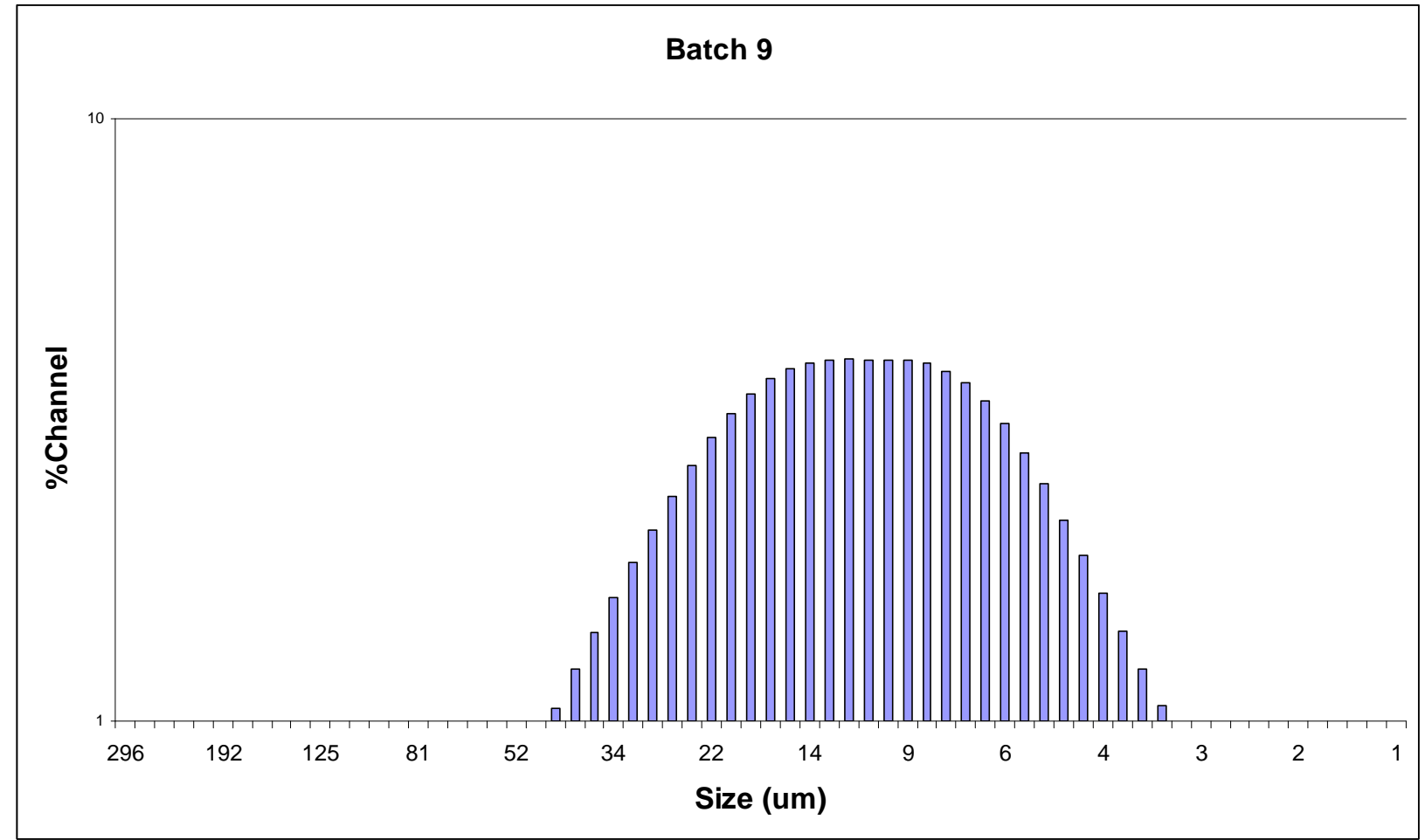

Batch 10

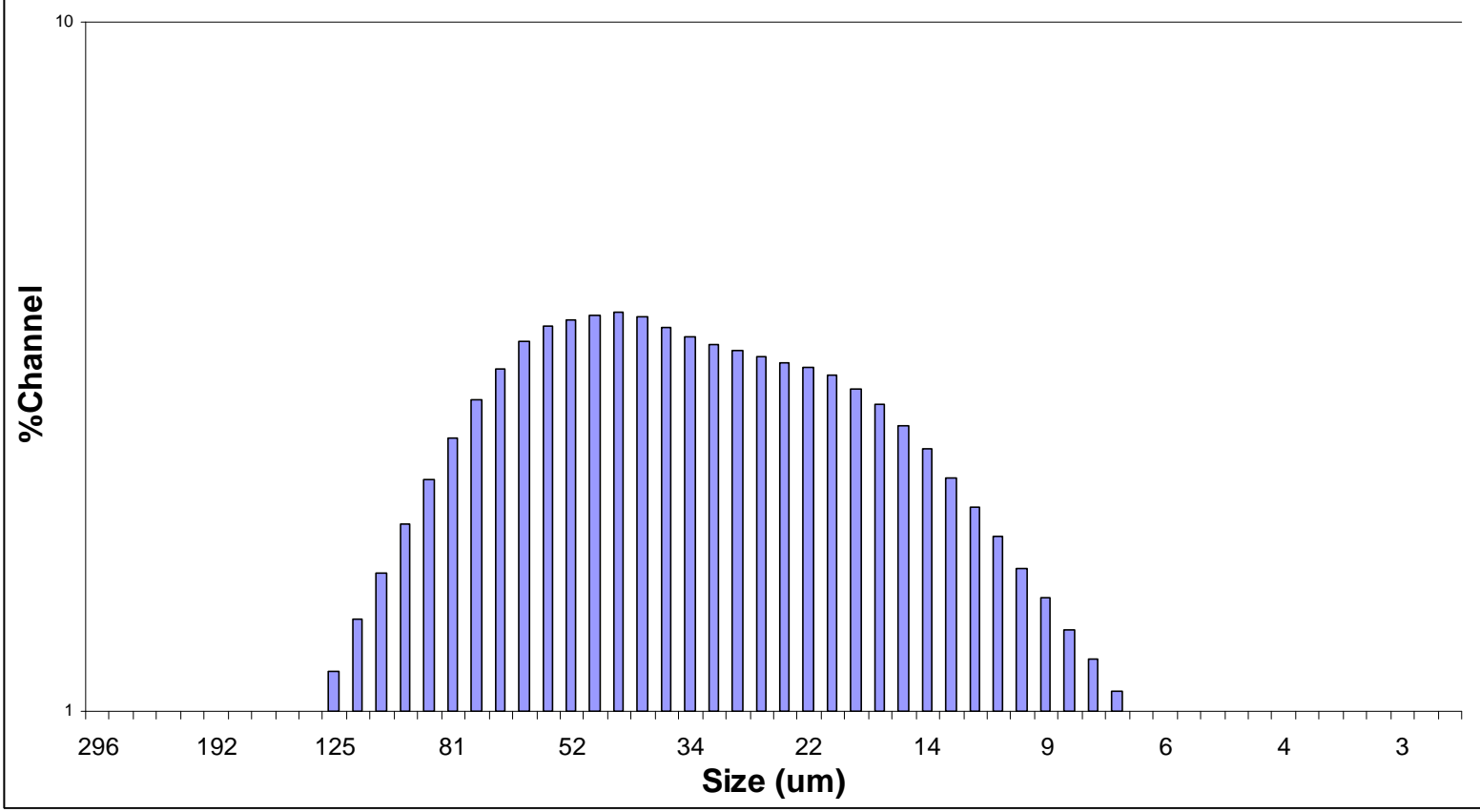


Exhibit A-2: Summary of rheology calculations

\begin{tabular}{|r|c|c|c|c|c|c|c|c|c||}
\hline \hline Run & $\begin{array}{c}\text { Initial } \\
\text { IS } \\
\text { wt \% }\end{array}$ & $\begin{array}{c}\text { Up } \\
\text { Yield } \\
\text { Pa }\end{array}$ & $\begin{array}{c}\text { Down } \\
\text { Yield } \\
\text { Pa }\end{array}$ & $\begin{array}{c}\text { 2nd IS } \\
\text { wt \% }\end{array}$ & $\begin{array}{c}\text { Up } \\
\text { Yield } \\
\text { Pa }\end{array}$ & $\begin{array}{c}\text { Down } \\
\text { Yield } \\
\text { Pa }\end{array}$ & $\begin{array}{c}\text { Max } \\
\text { IS } \\
\text { wt \% }\end{array}$ & $\begin{array}{c}\text { Up } \\
\text { Yield } \\
\text { Pa }\end{array}$ & $\begin{array}{c}\text { Down Yield } \\
\text { Pa }\end{array}$ \\
\hline 1A & 8.114 & 1.43 & 1.19 & 10.017 & 3.51 & 2.97 & 11.681 & 7.18 & 5.71 \\
\hline 2 & 8.499 & 0.92 & 0.65 & 10.492 & 2.21 & 1.50 & 14.194 & 9.77 & 3.11 \\
\hline 3 & 8.815 & 0.75 & 0.48 & 10.883 & 1.61 & 1.08 & 14.612 & 6.04 & 3.13 \\
\hline 4 & 7.912 & 0.88 & 0.70 & 9.768 & 2.40 & 1.87 & 11.593 & 8.38 & 3.92 \\
\hline 5 & 8.109 & 0.93 & 0.80 & 10.012 & 1.87 & 1.60 & 12.778 & 5.66 & 3.76 \\
\hline 6 & 8.404 & 0.76 & 0.58 & 10.375 & 1.72 & 1.41 & 13.671 & 7.33 & 2.50 \\
\hline 7 & 8.140 & 0.66 & 0.55 & 10.049 & 1.56 & 1.27 & 12.397 & 5.24 & 3.11 \\
\hline 8 & 8.701 & 0.96 & 0.76 & 10.742 & 2.24 & 1.83 & 13.343 & 6.27 & 4.29 \\
\hline 9 & 8.024 & 0.50 & 0.35 & 9.907 & 1.06 & 0.77 & 13.868 & 7.06 & 2.94 \\
\hline 10 & 8.397 & 1.21 & 0.90 & 10.367 & 2.86 & 2.11 & 12.339 & 6.60 & 4.19 \\
\hline
\end{tabular}


Exhibit A-2: Rheology data for batches 1A-10
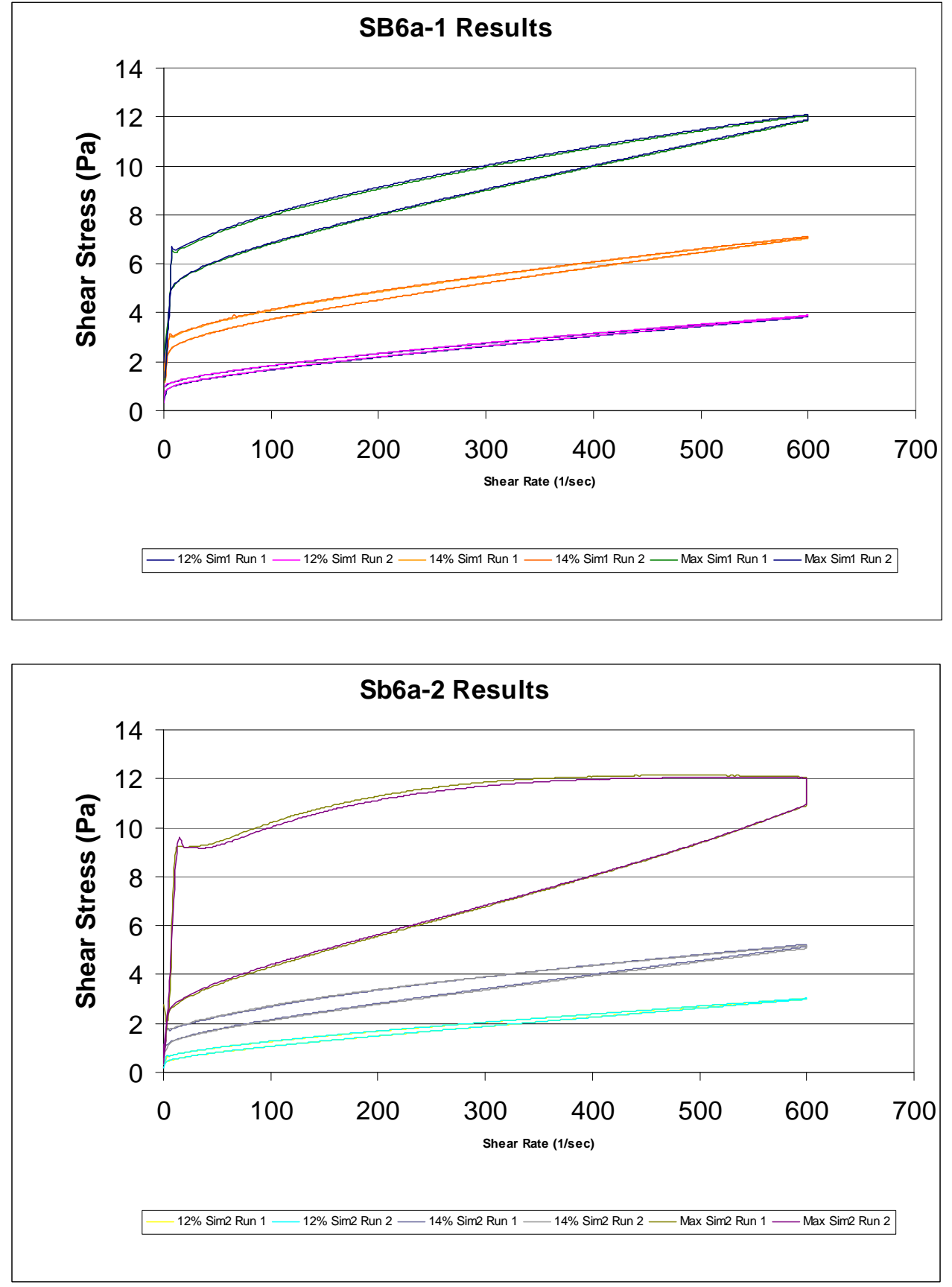
SRNL-STI-2009-00603

Revision 0

Exhibit A-2: Rheology data for batches 1A-10 (cont.)
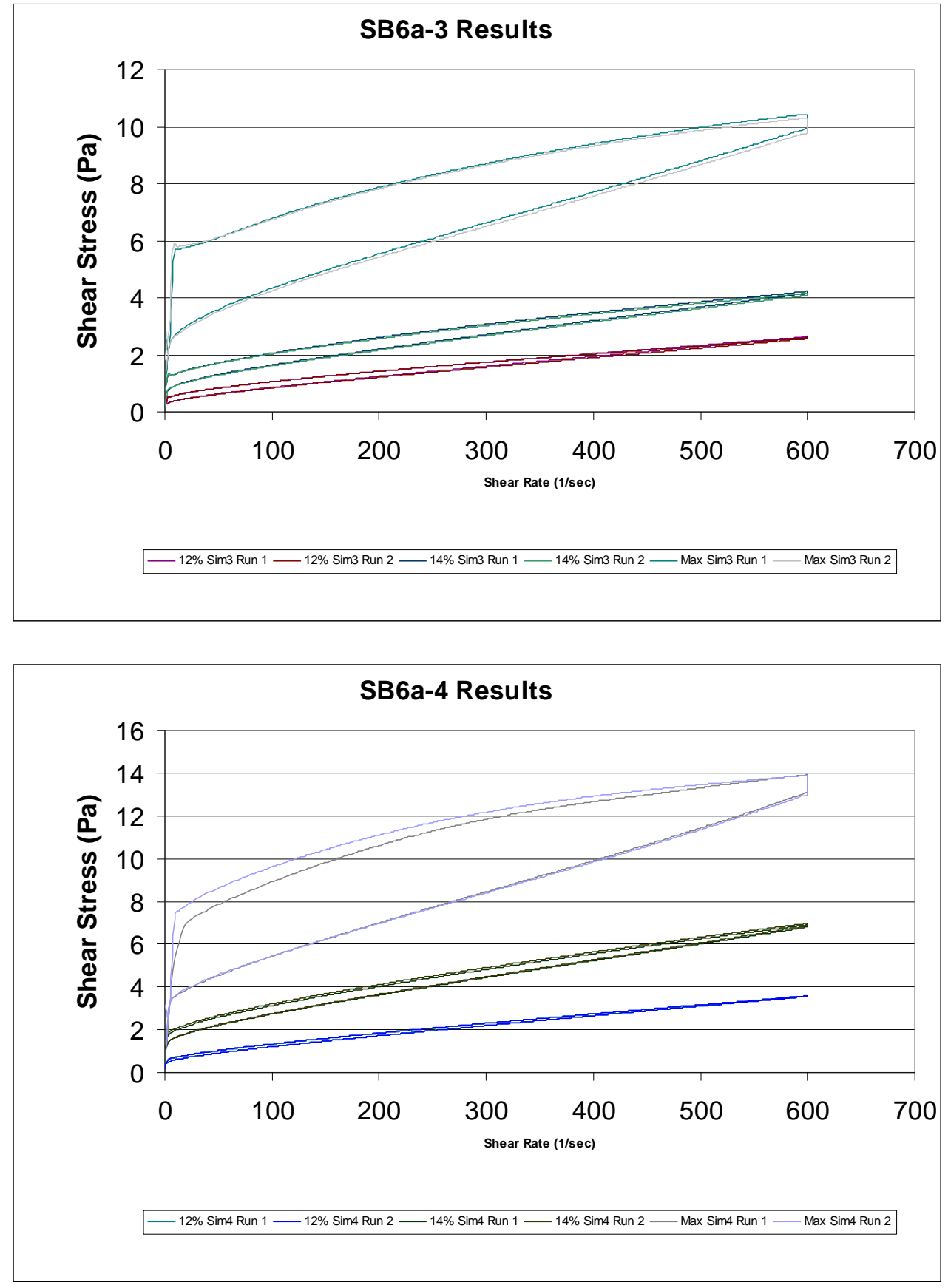
Exhibit A-2: Rheology data for batches 1A-10 (cont.)
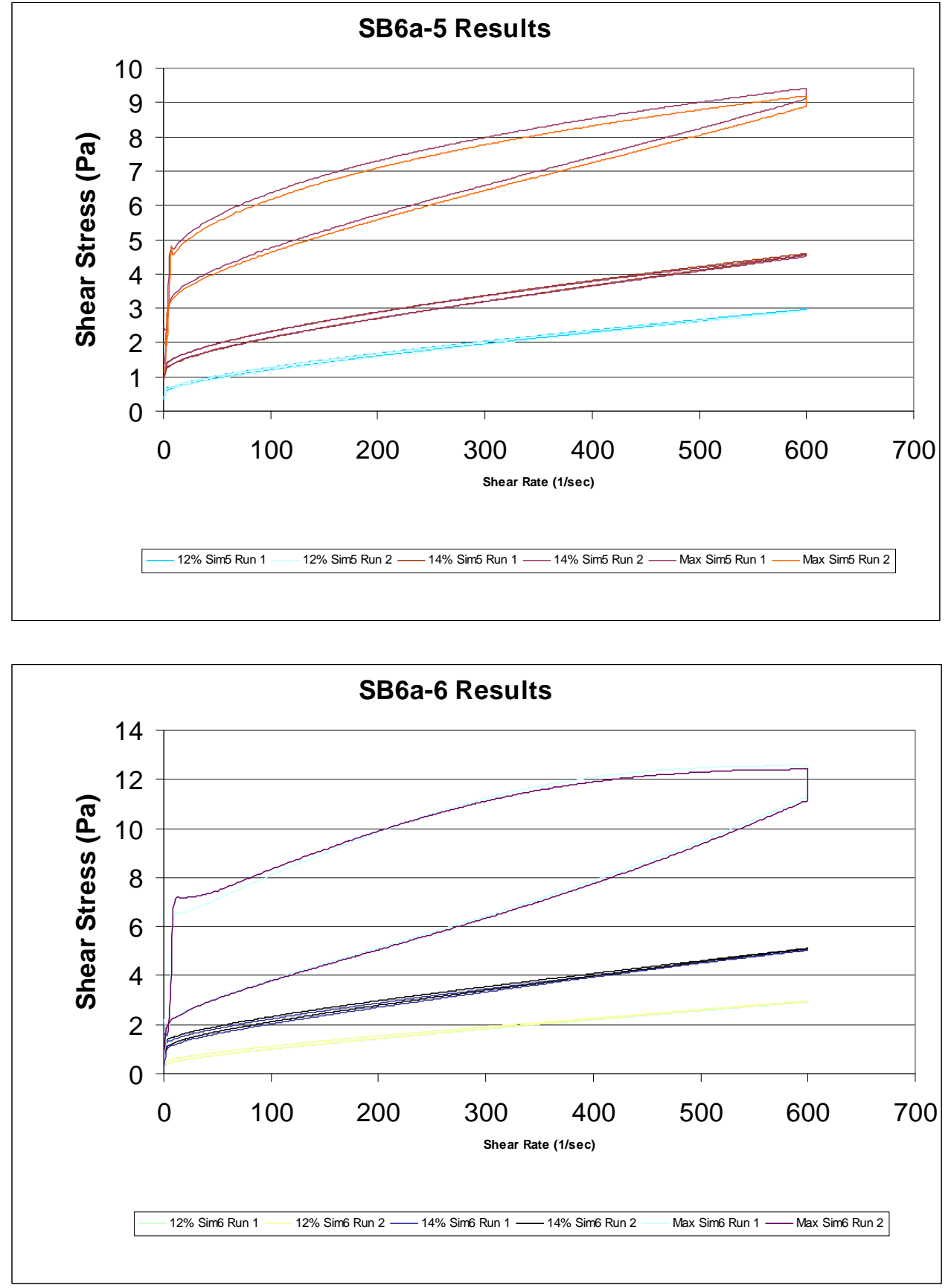
Exhibit A-2: Rheology data for batches 1A-10 (cont.)
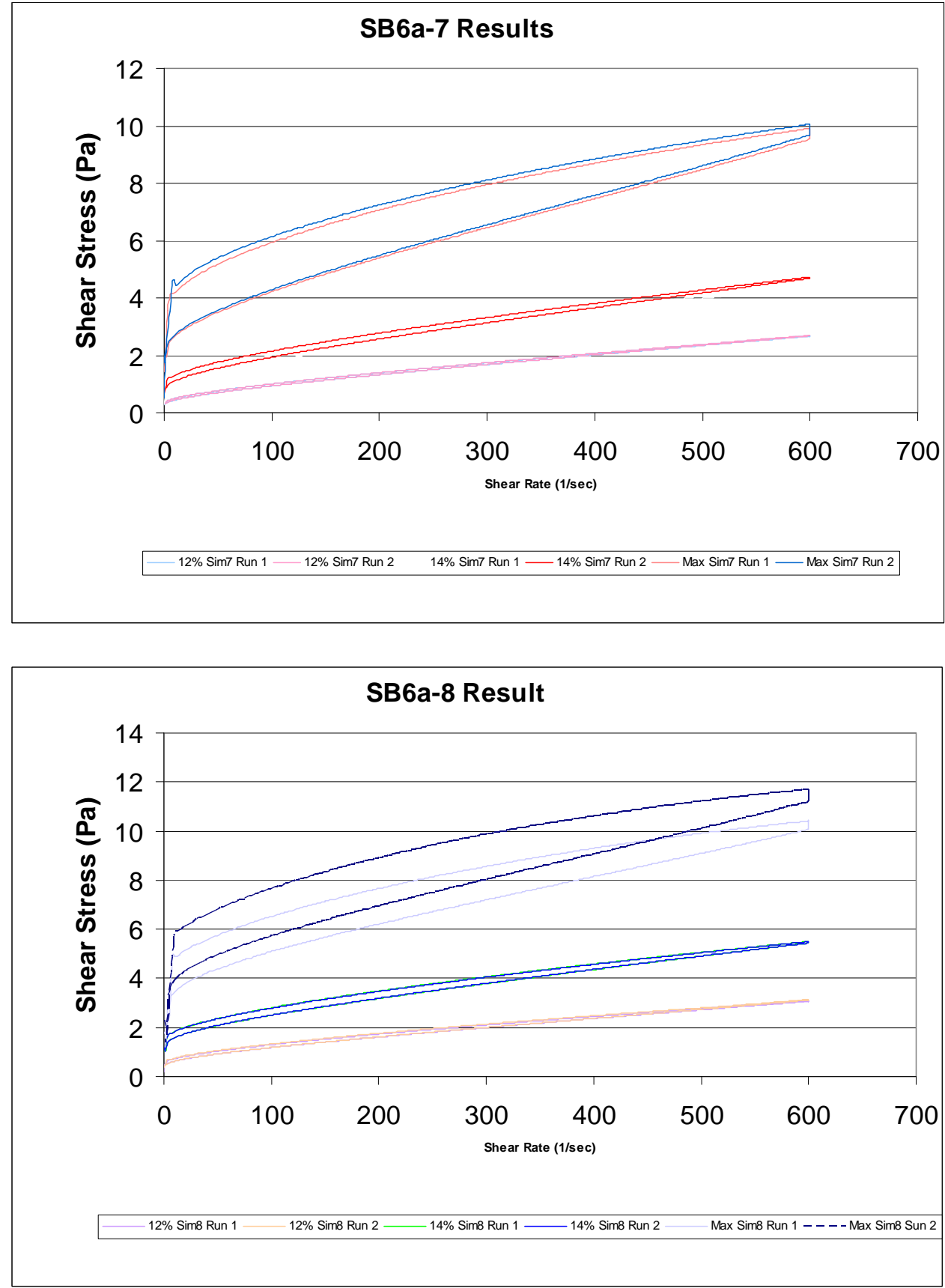
Exhibit A-2: Rheology data for batches 1A-10 (cont.)
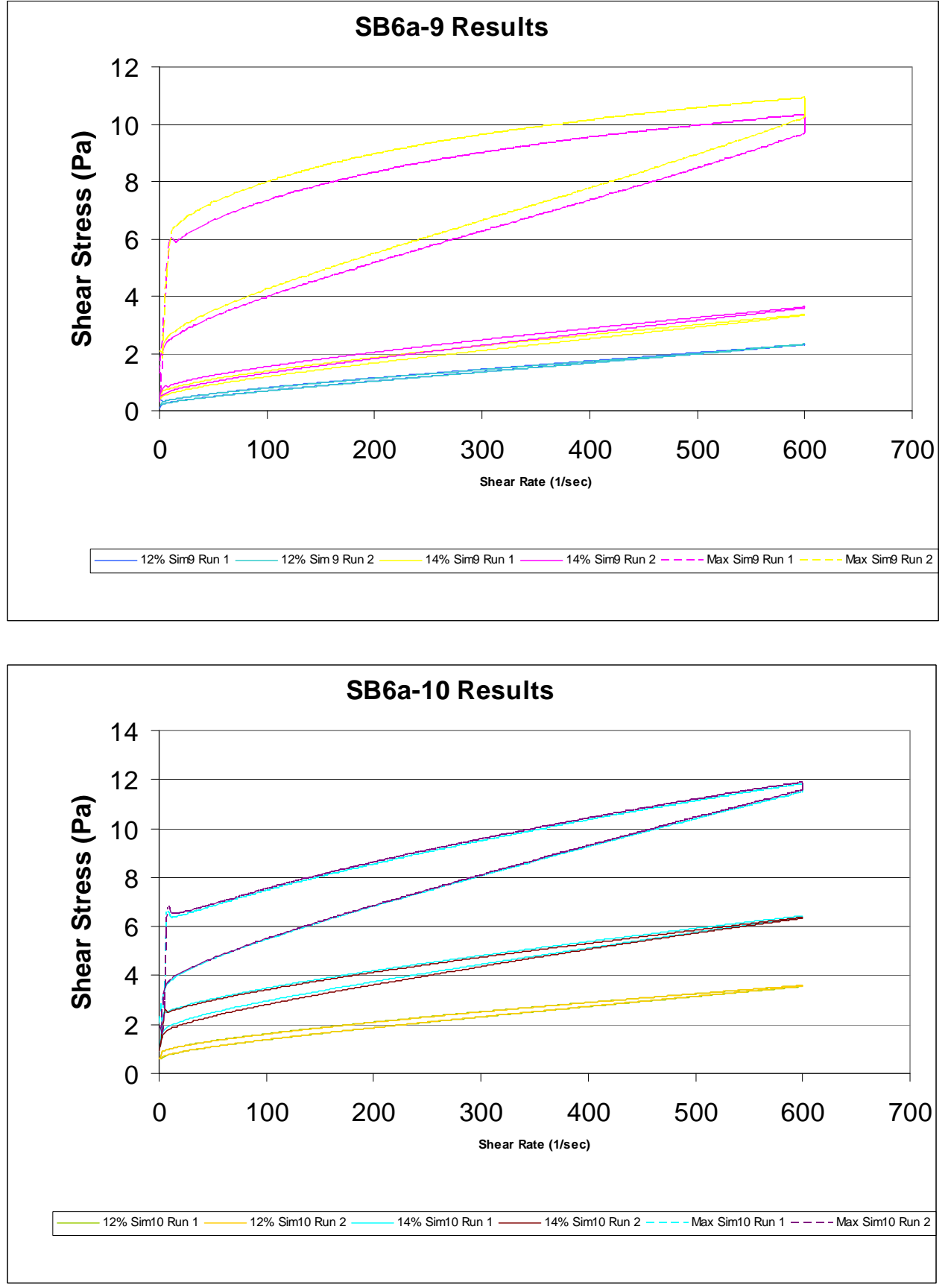
Exhibit A-2: Rheology data for batches 1A-10 (cont.)
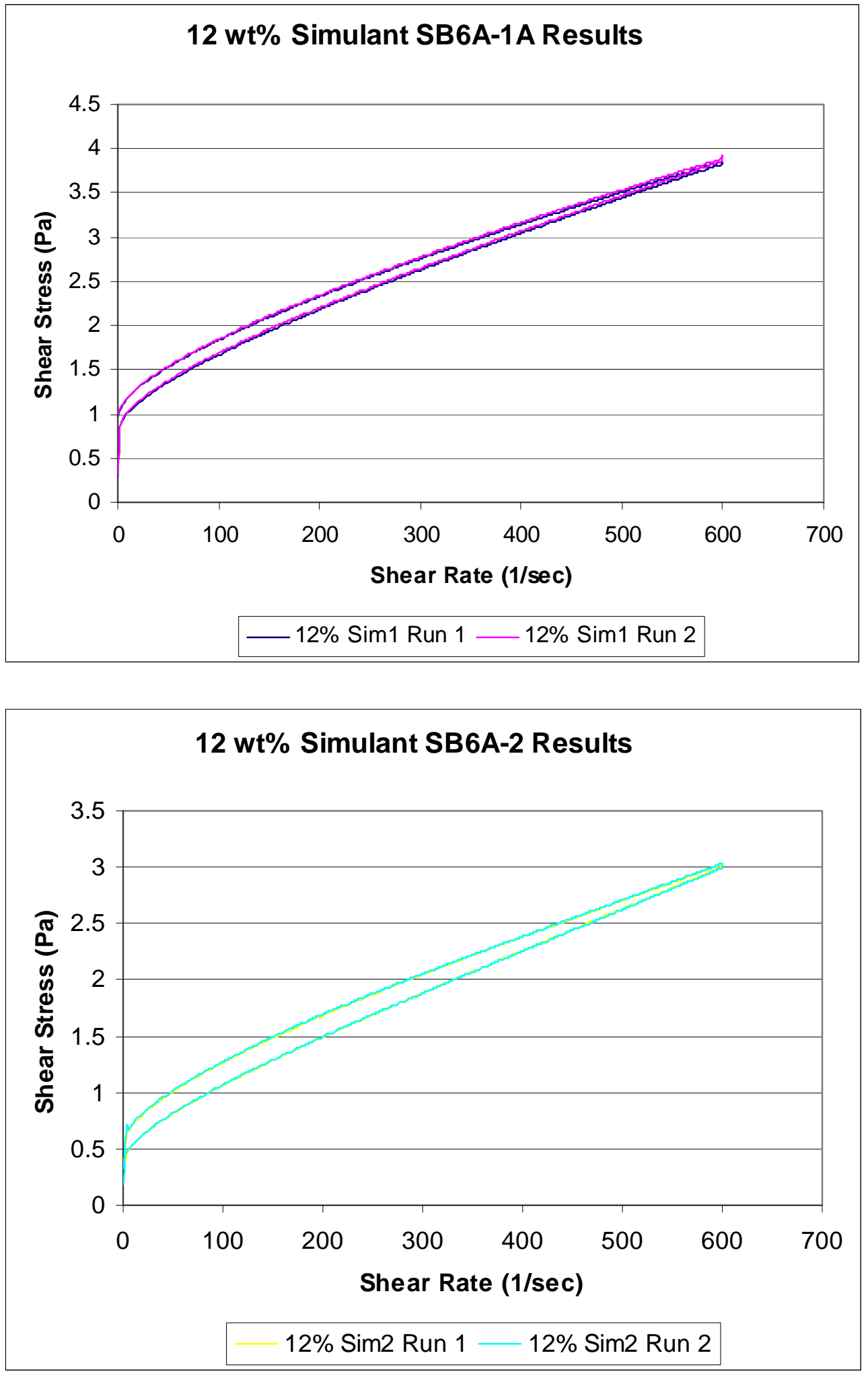
Exhibit A-2: Rheology data for batches 1A-10 (cont.)
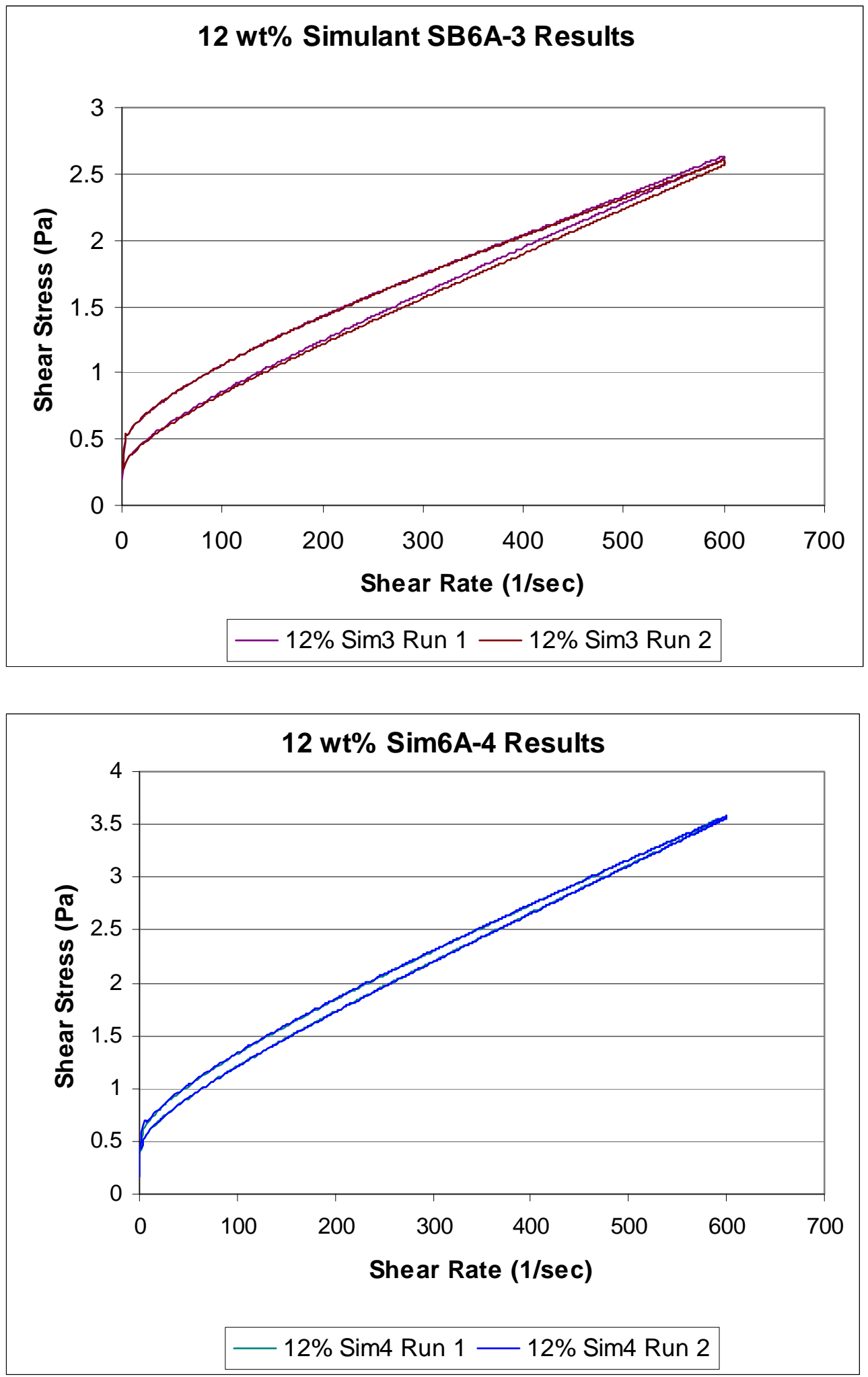
Exhibit A-2: Rheology data for batches 1A-10 (cont.)
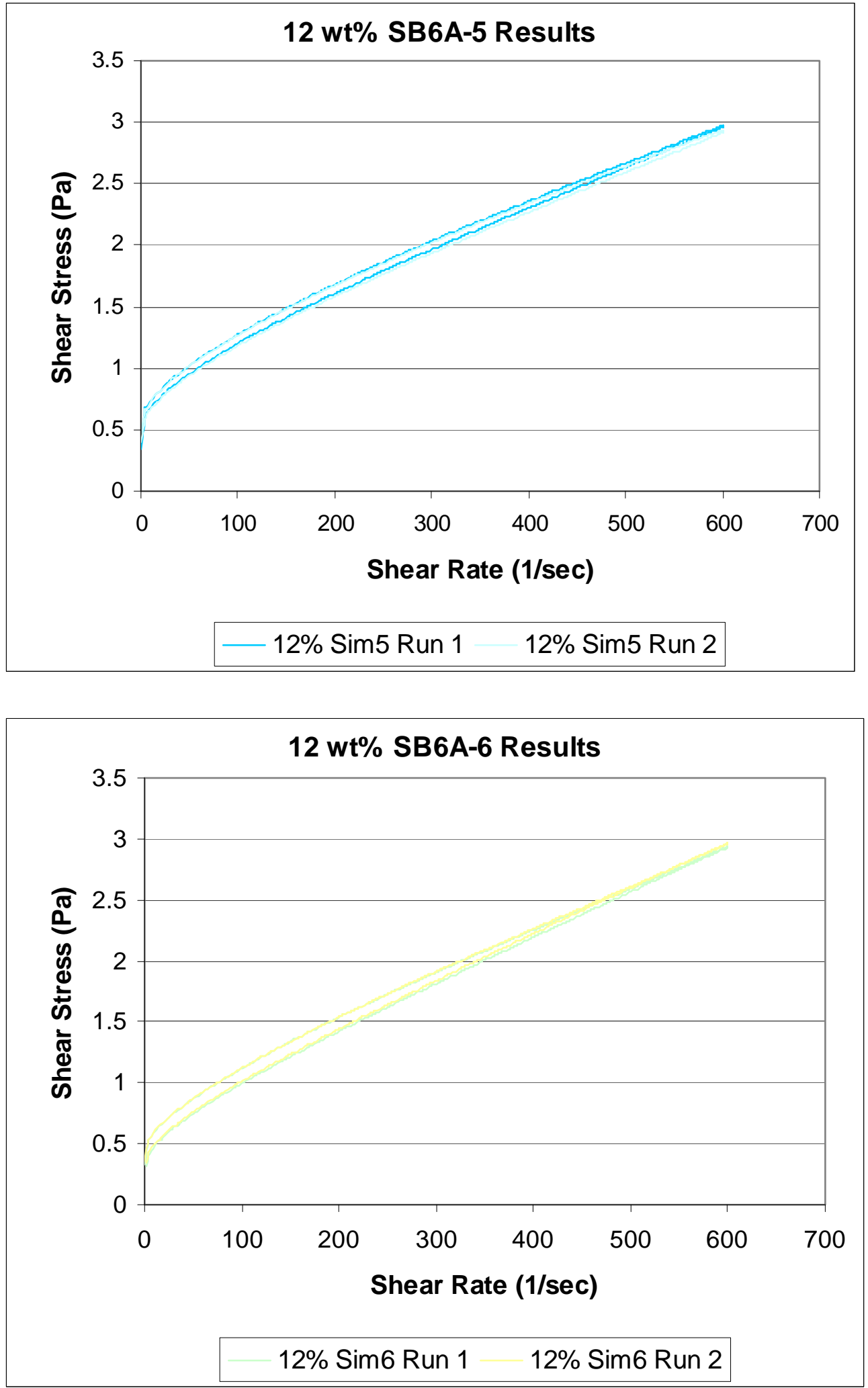
Exhibit A-2: Rheology data for batches 1A-10 (cont.)
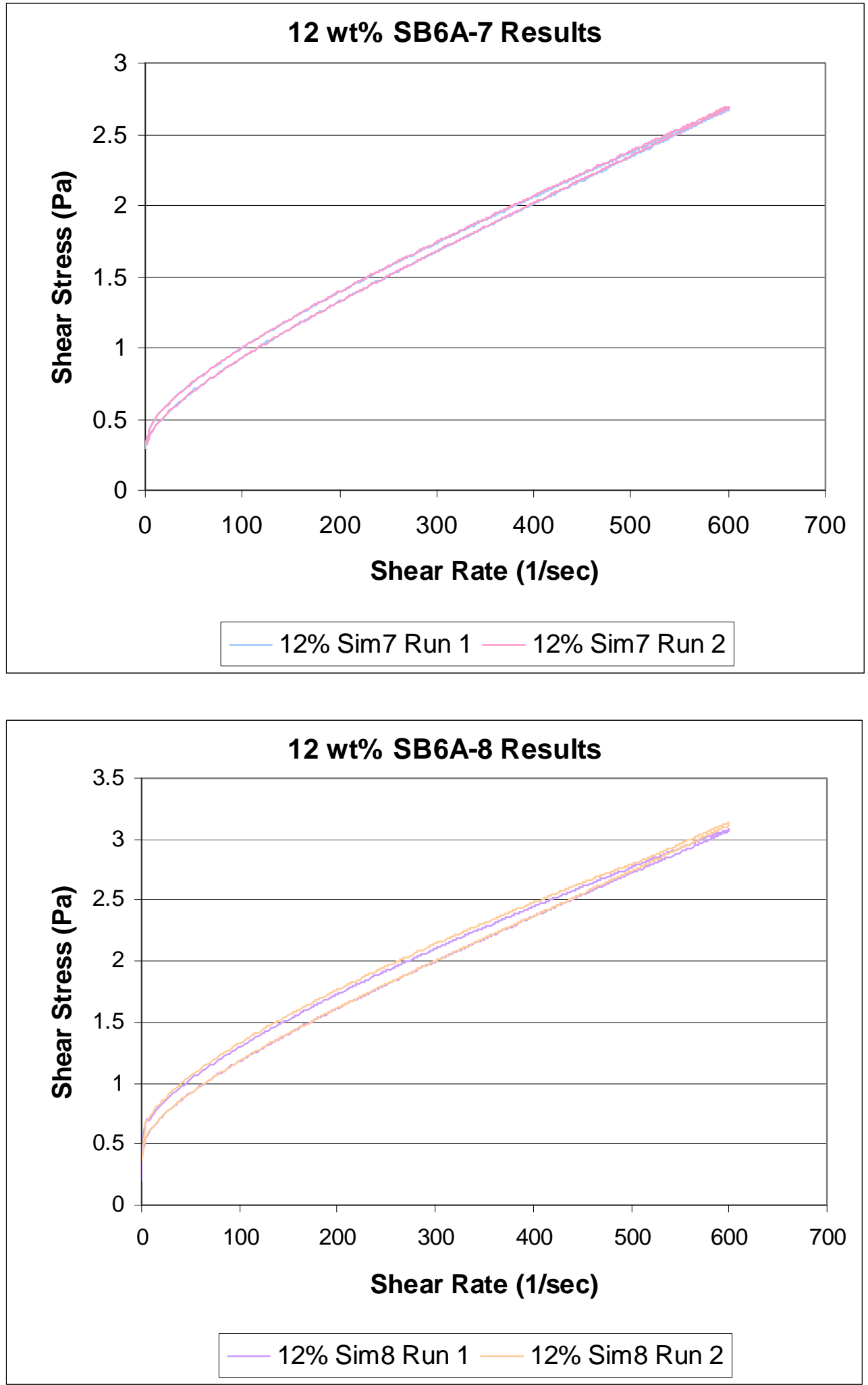
Exhibit A-2: Rheology data for batches 1A-10 (cont.)
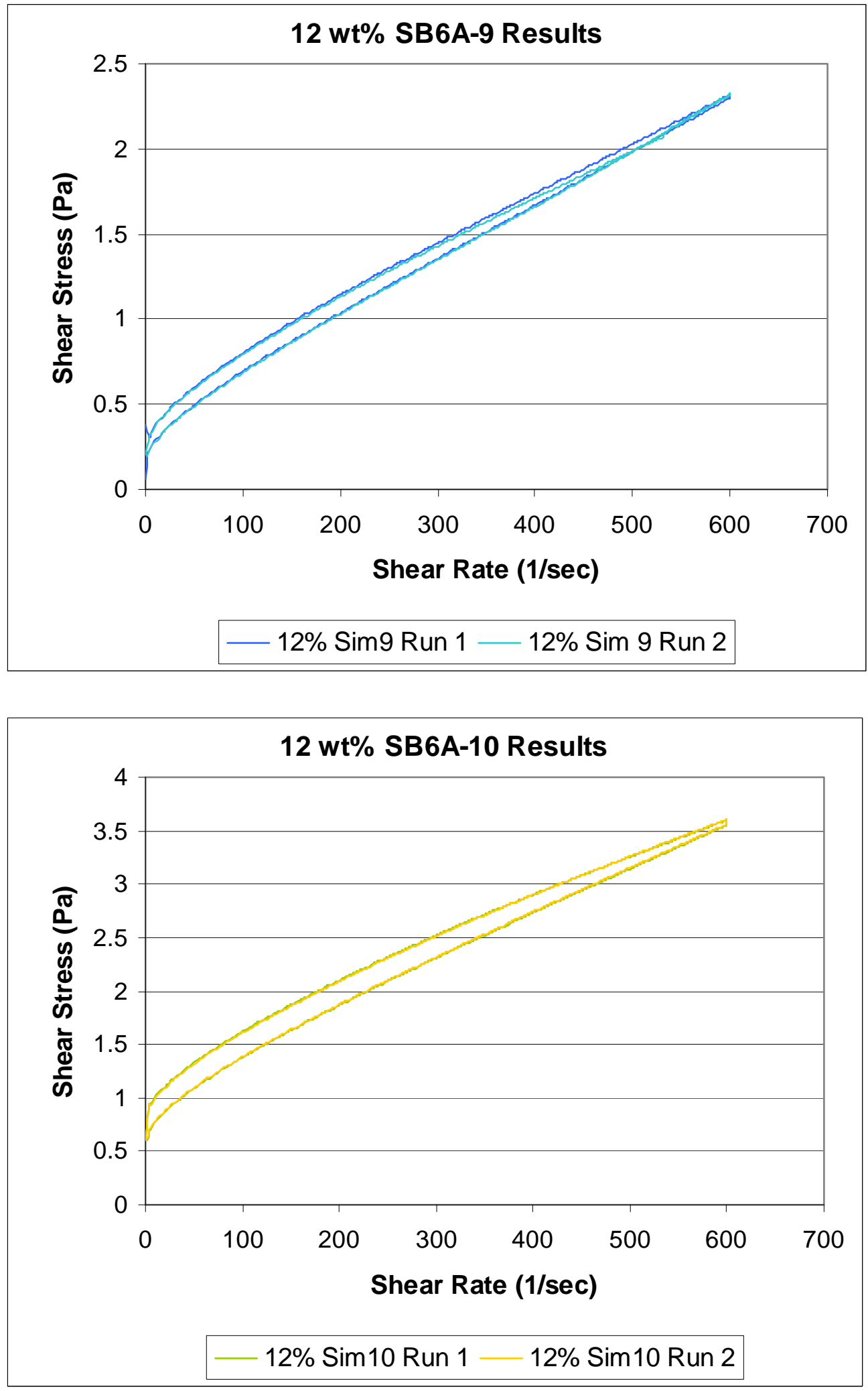
Exhibit A-2: Rheology data for batches 1A-10 (cont.)
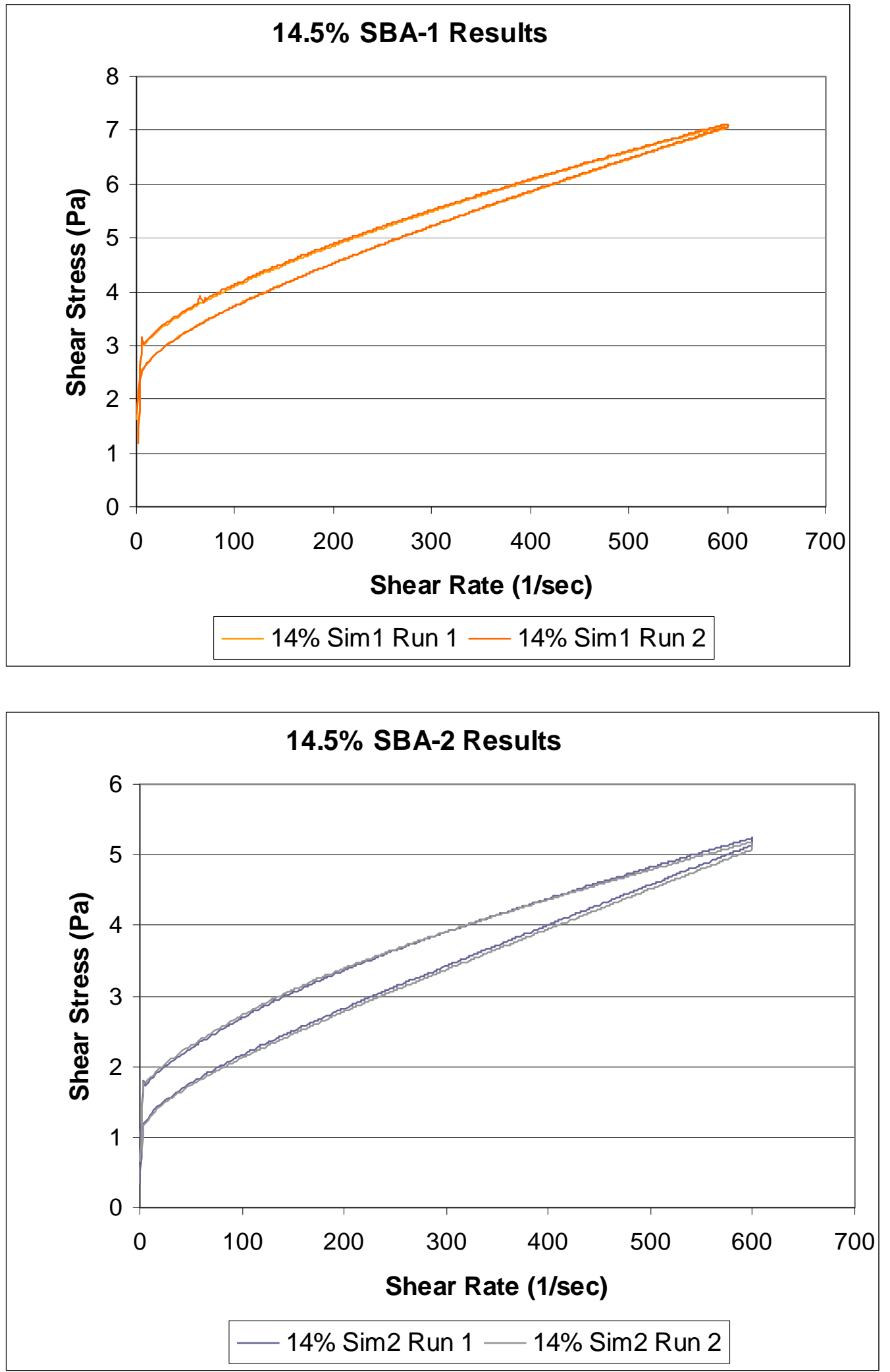
Exhibit A-2: Rheology data for batches 1A-10 (cont.)
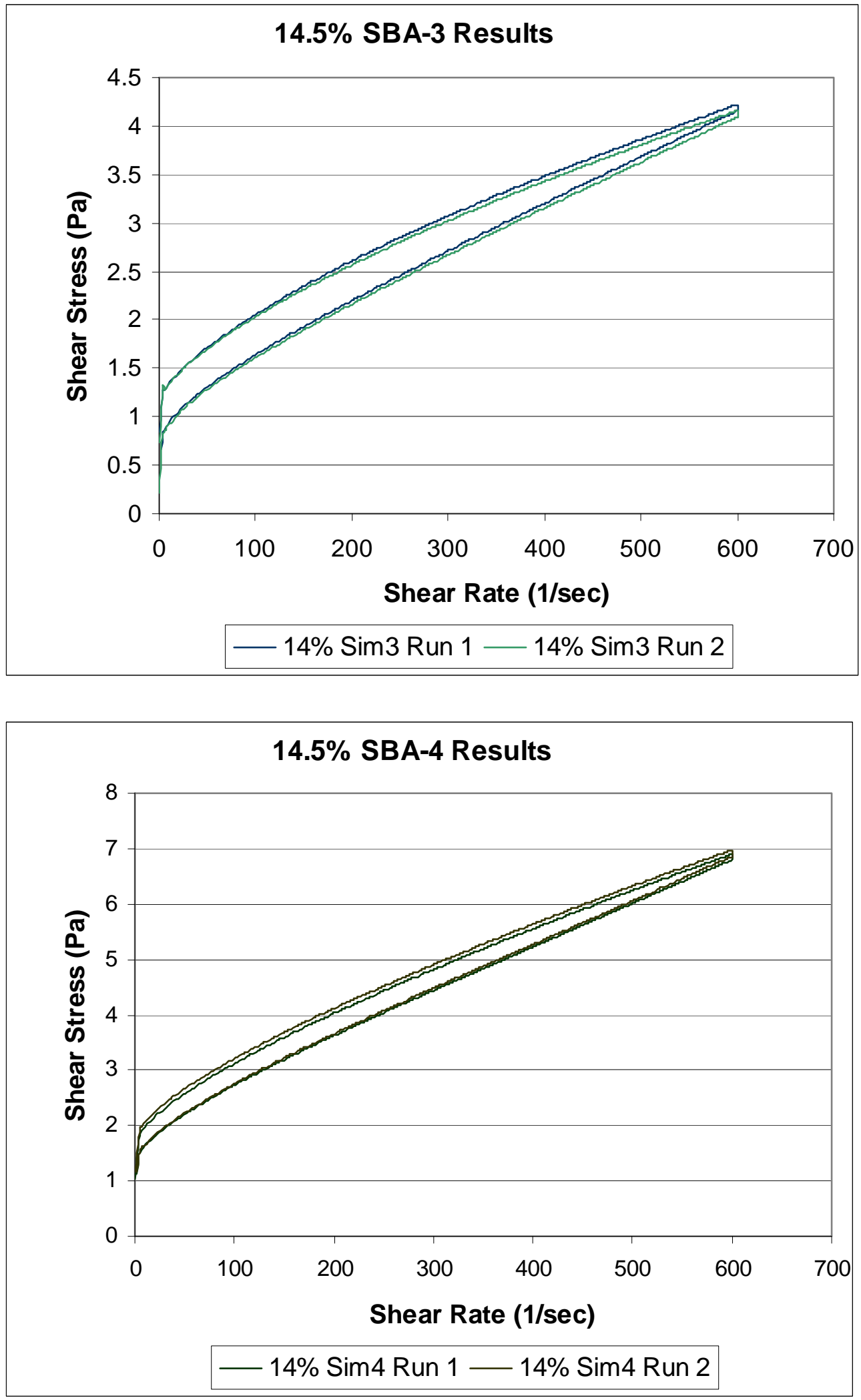
Exhibit A-2: Rheology data for batches 1A-10 (cont.)
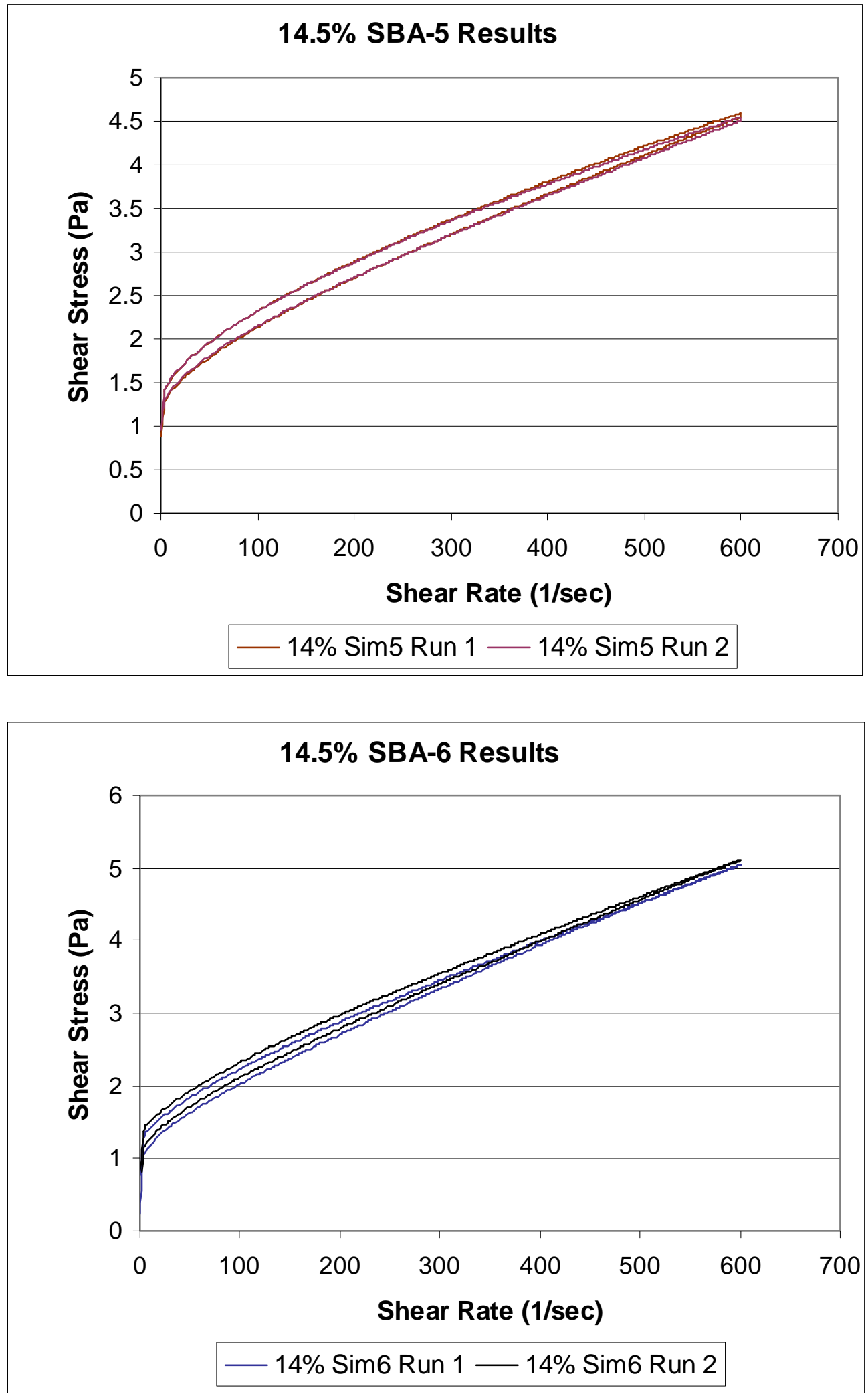
Exhibit A-2: Rheology data for batches 1A-10 (cont.)
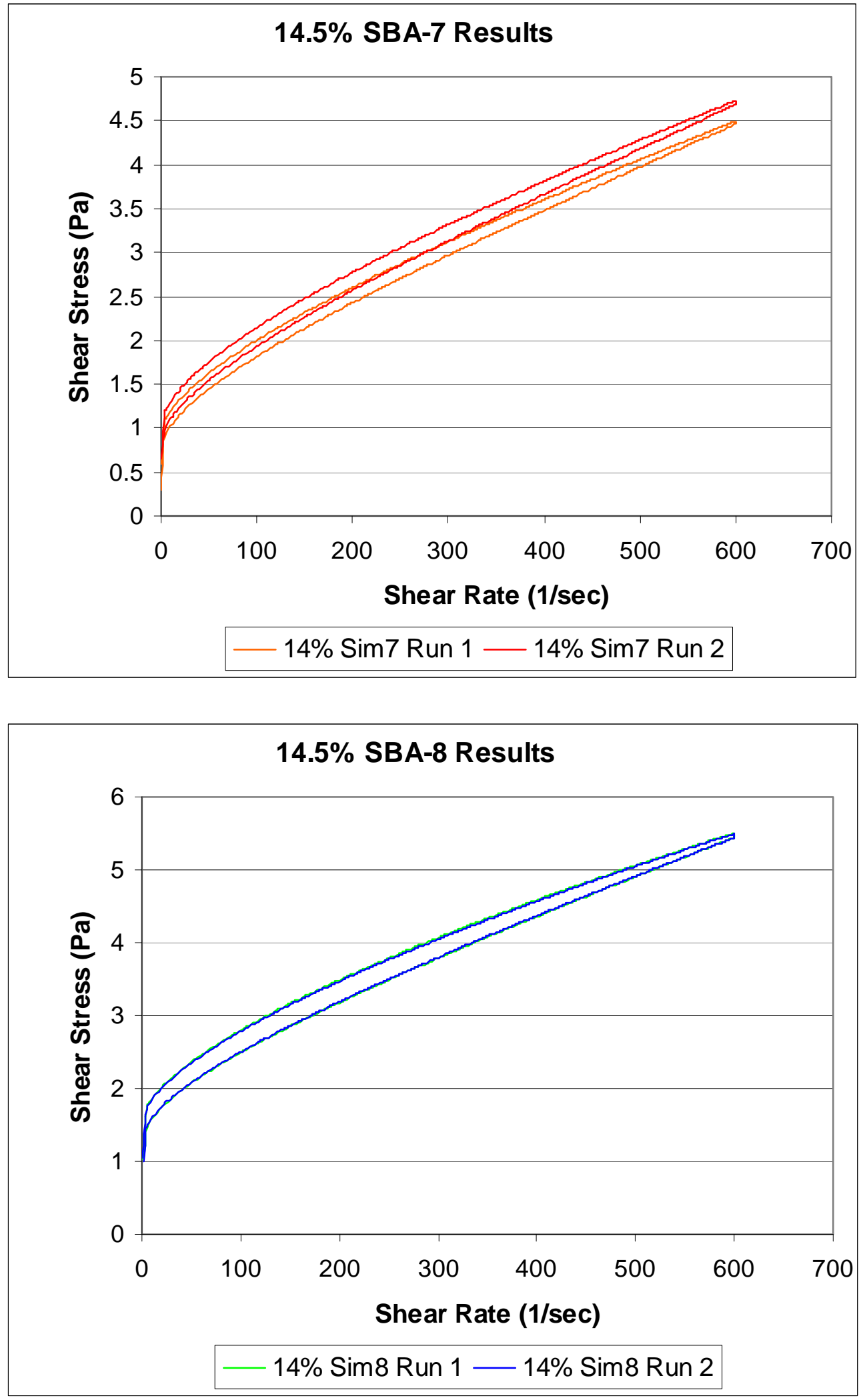
Exhibit A-2: Rheology data for batches 1A-10 (cont.)
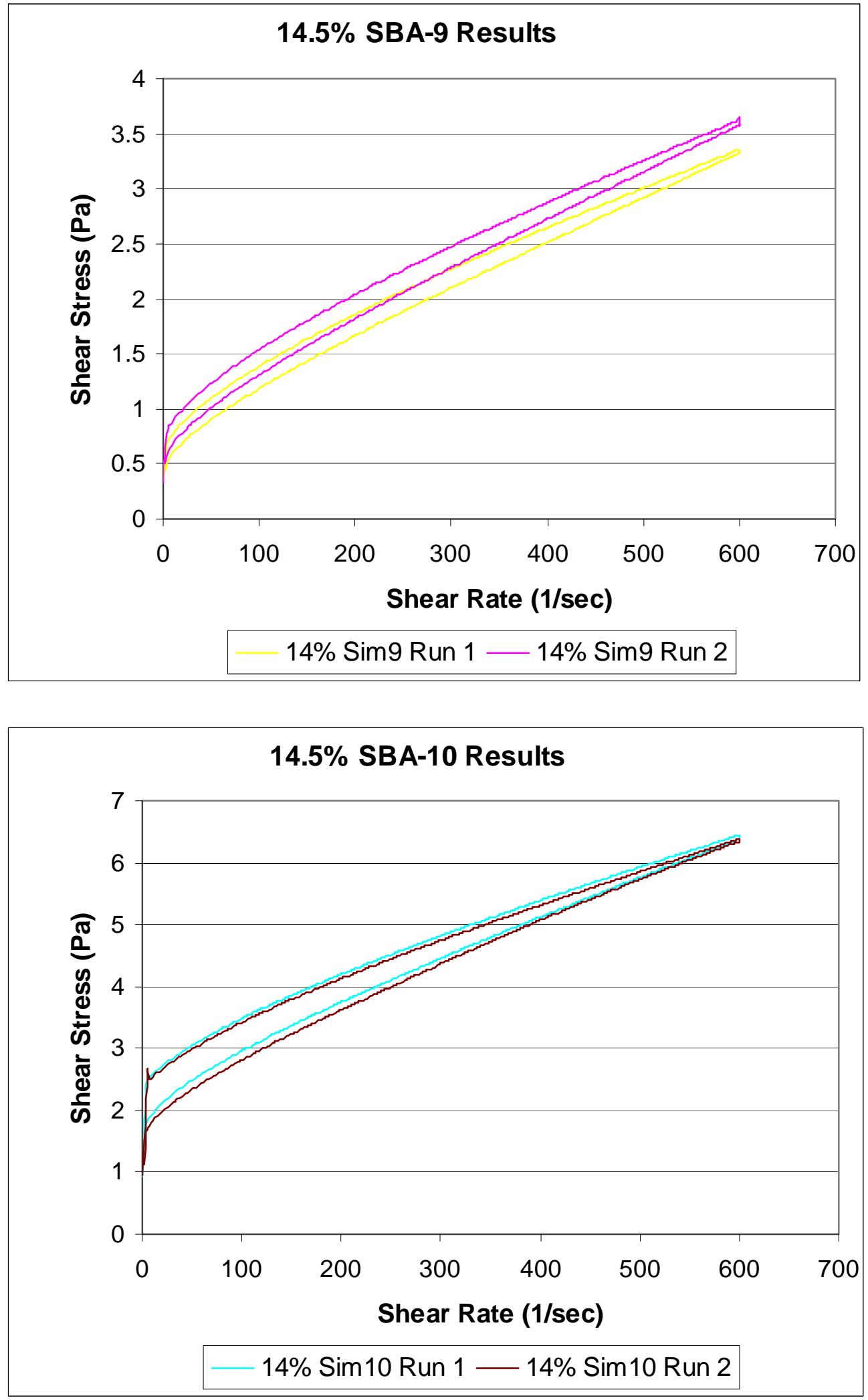
Exhibit A-2: Rheology data for batches 1A-10 (cont.)
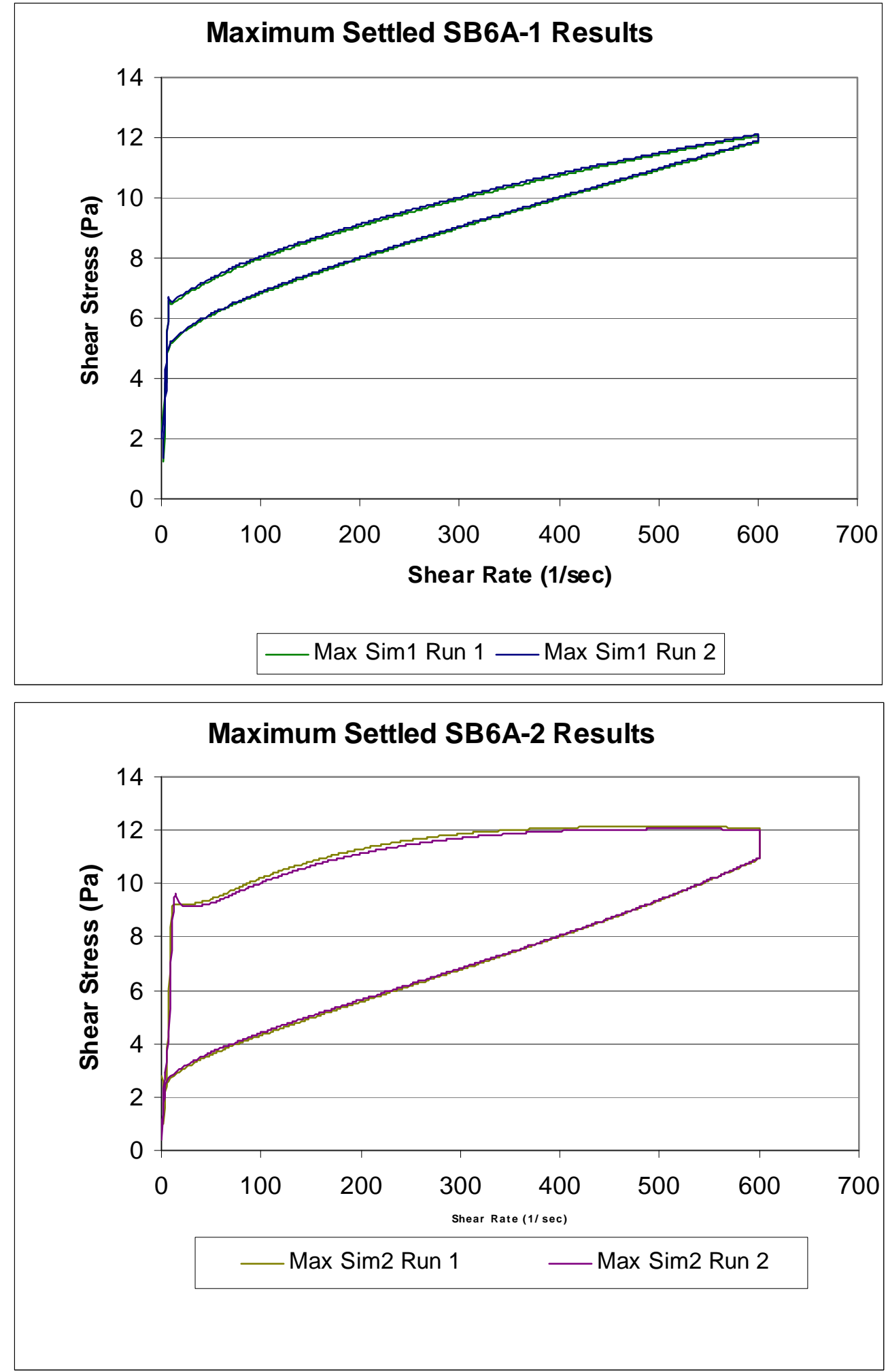
Exhibit A-2: Rheology data for batches 1A-10 (cont.)
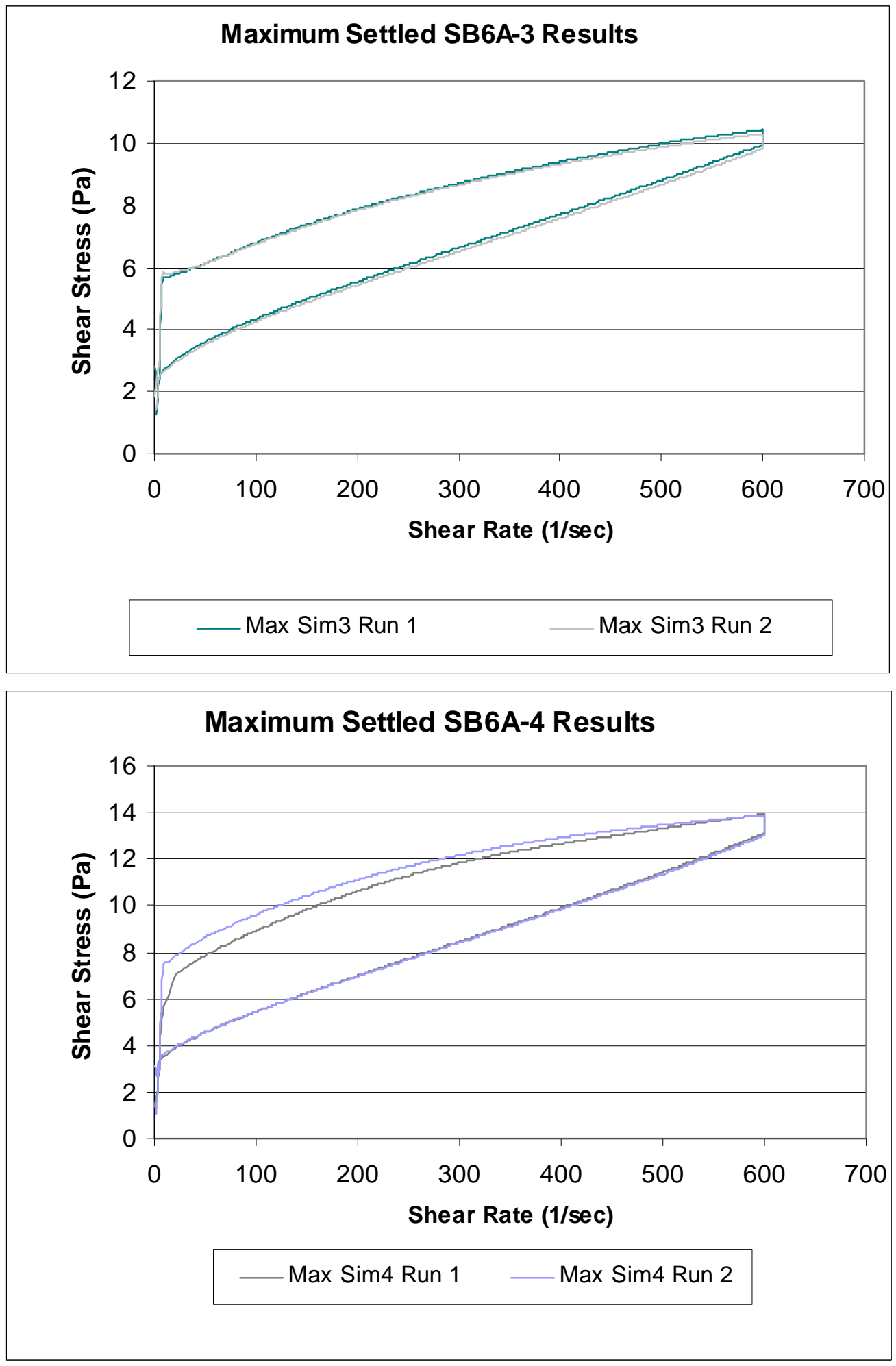
Exhibit A-2: Rheology data for batches 1A-10 (cont.)
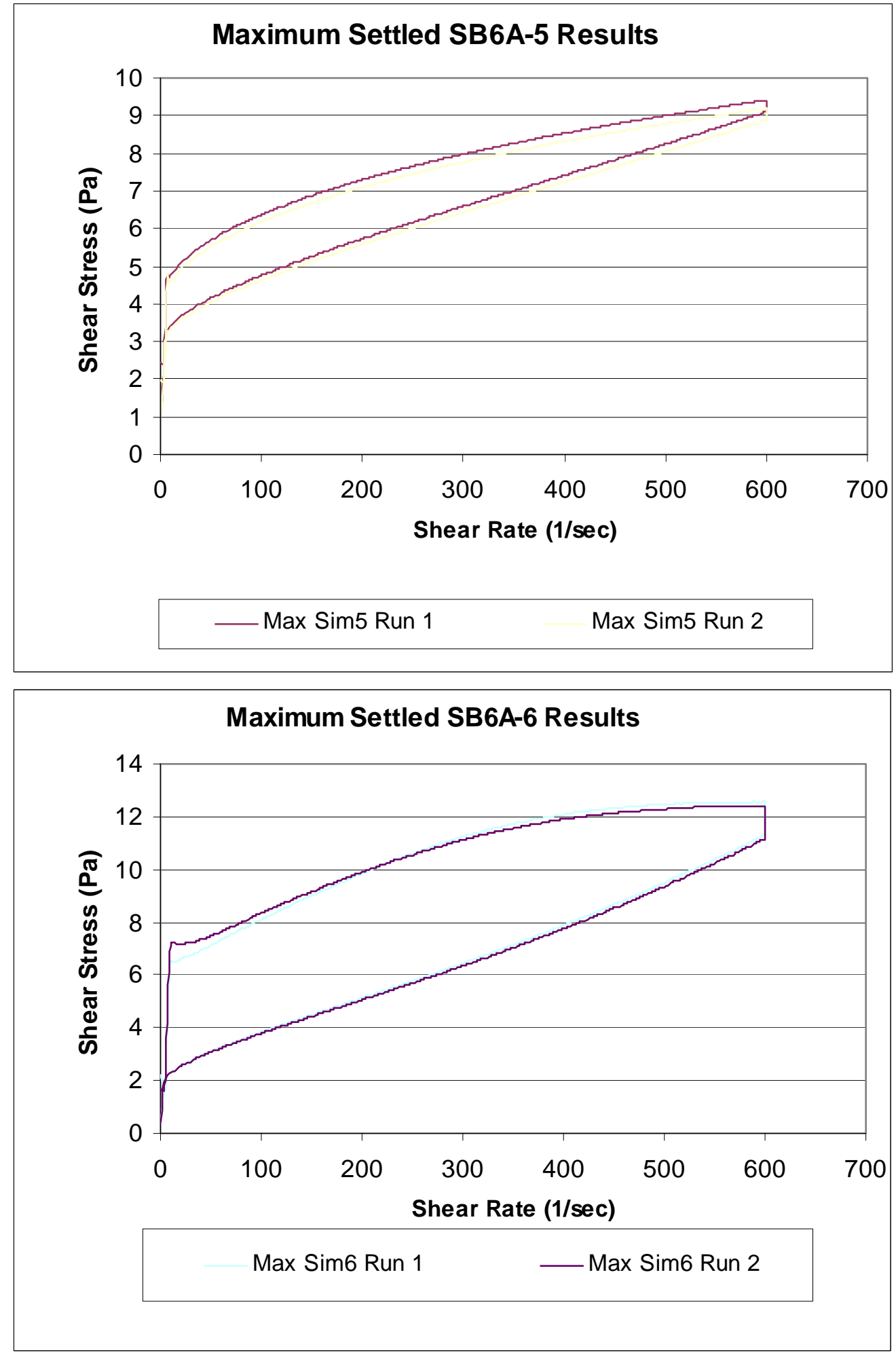
Exhibit A-2: Rheology data for batches 1A-10 (cont.)
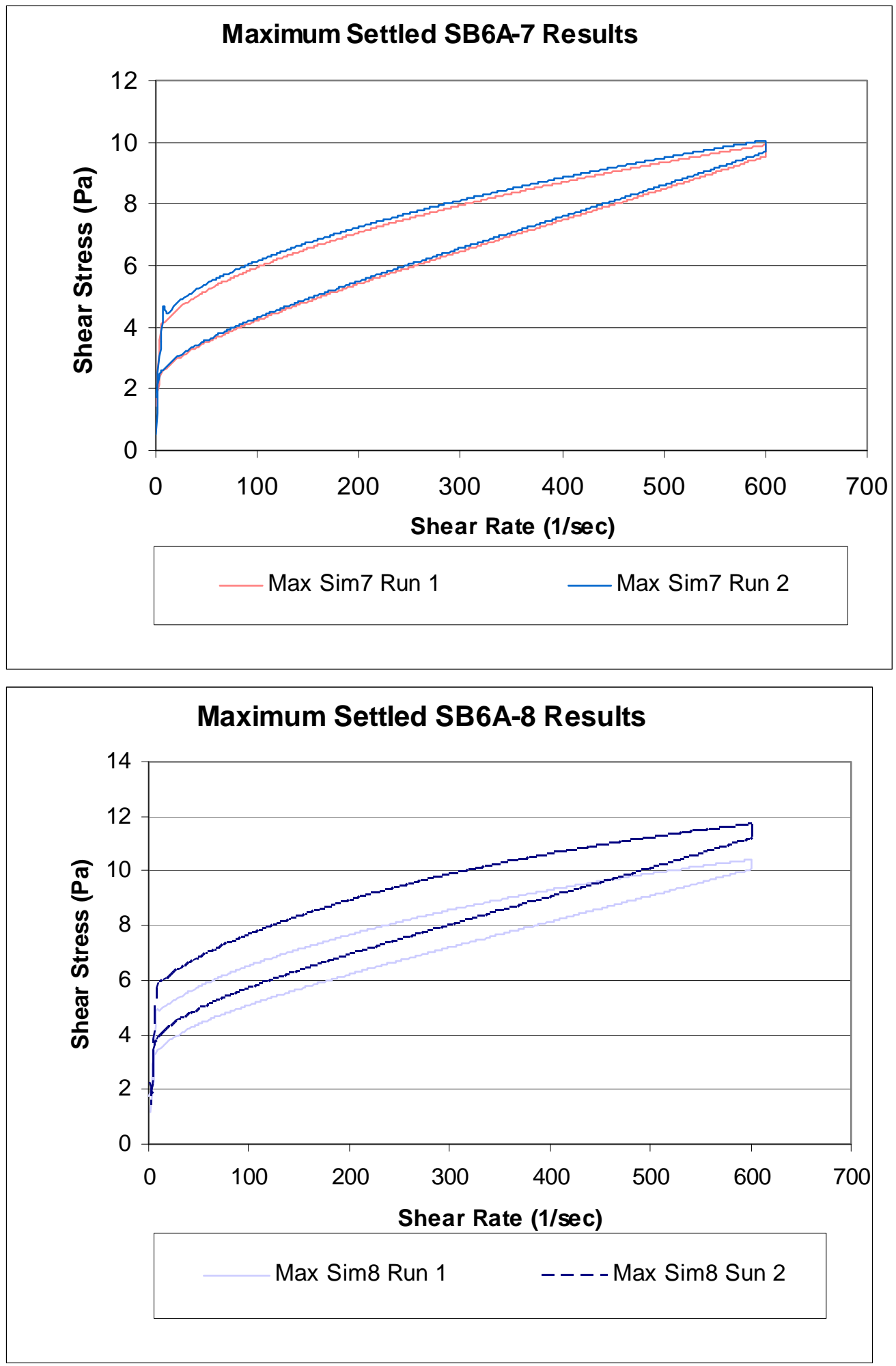
Exhibit A-2: Rheology data for batches 1A-10 (cont.)
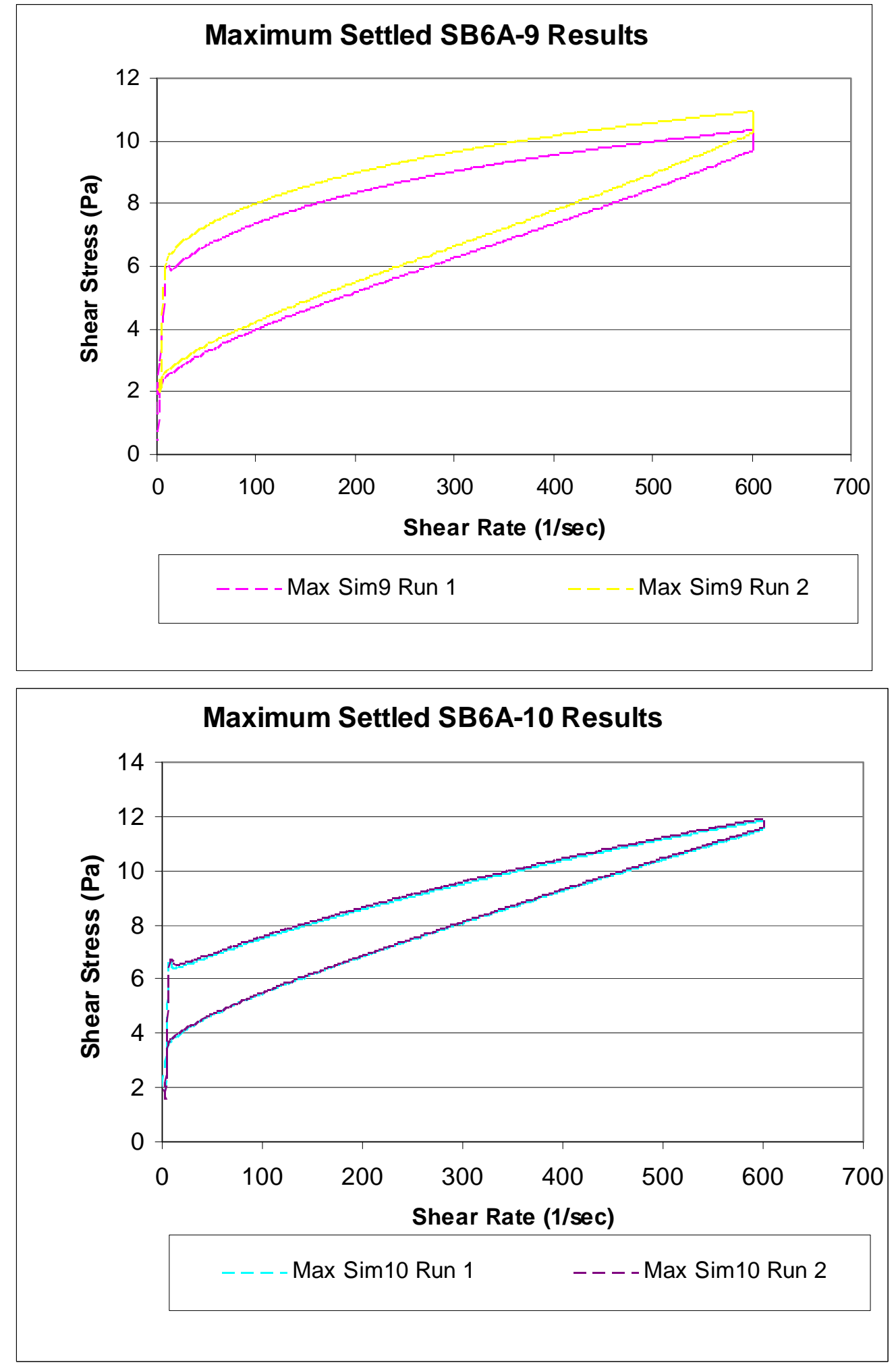


\section{Distribution:}
A. B. Barnes, 999-W
D. A. Crowley, 773-43A
S. D. Fink, 773-A
B. J. Giddings, 786-5A
C. C. Herman, 999-W
S. L. Marra, 773-A
F. M. Pennebaker, 773-42A
C. J. Bannochie, 773-42A
J. M. Gillam, 766-H
B. A. Hamm, 766-H
J. F. Iaukea, 704-30S
R. T. McNew, 704-27S
J. E. Occhipinti, 704-S
D. K. Peeler, 999-W
J. W. Ray, 704-S
H. B. Shah, 766-H
D. C. Sherburne, 704-S
M. E. Stone, 999-W

J. M. Bricker, 704-27S

T. L. Fellinger, 704-26S

E. W. Holtzscheiter, 704-15S

M. T. Keefer, 766-H

J. D. Newell, 999-W

D. P. Lambert, 999-W

D. C. Koopman, 999-W

A. I. Fernandez, 999-W

B. R. Pickenheim, 999-W 